\title{
The Angelman Syndrome Protein Ube3a/E6AP Is Required for Golgi Acidification and Surface Protein Sialylation
}

\author{
Kathryn H. Condon, ${ }^{1}$ Jianghai Ho, ${ }^{1}$ Camenzind G. Robinson, ${ }^{1}$ Cyril Hanus, ${ }^{1}$ and Michael D. Ehlers ${ }^{1,2}$ \\ ${ }^{1}$ Department of Neurobiology, Duke University Medical Center, Durham, North Carolina 27710, and ${ }^{2}$ Pfizer Worldwide Research and Development, \\ Neuroscience Research Unit, Cambridge, Massachusetts 02139
}

\begin{abstract}
Angelman syndrome (AS) is a severe disorder of postnatal brain development caused by neuron-specific loss of the HECT (homologous to E6AP carboxy terminus) domain E3 ubiquitin ligase Ube3a/E6AP. The cellular role of Ube3a remains enigmatic despite recent descriptions of synaptic and behavioral deficits in AS mouse models. Although neuron-specific imprinting is thought to limit the disease to the brain, Ube3a is expressed ubiquitously, suggesting a broader role in cellular function. In the current study, we demonstrate a profound structural disruption and cisternal swelling of the Golgi apparatus (GA) in the cortex of AS $\left(U B E 3 A^{\mathrm{m}-/ \mathrm{p}^{+}}\right)$mice. In Ube3a knockdown cell lines and $U B E 3 A^{\mathrm{m}-/ \mathrm{p}+}$ cortical neurons, the GA is severely under-acidified, leading to osmotic swelling. Both in vitro and in vivo, the loss of Ube3a and corresponding elevated $\mathrm{pH}$ of the $\mathrm{GA}$ is associated with a marked reduction in protein sialylation, a process highly dependent on intralumenal Golgi pH. Altered ion homeostasis of the GA may provide a common cellular pathophysiology underlying the diverse plasticity and neurodevelopmental deficits associated with AS.
\end{abstract}

\section{Introduction}

Angelman syndrome (AS) is a rare neurodevelopmental disorder caused by loss of the maternal copy of $U B E 3 A$, an imprinted gene encoding the E3 ubiquitin ligase Ube3a/E6AP (Chamberlain and Lalande, 2010). Along with severe developmental delay and ataxia, distinctive features of AS include frequent laughter and smiling, near absence of speech, and abnormal electroencephalogram patterns (Williams, 2010). UBE3A has been linked to autism (Nurmi et al., 2001; Bucan et al., 2009; Glessner et al., 2009), and maternal 15q11-13 microduplication, encompassing UBE3A, is among the most common genetic abnormalities observed in autism spectrum disorders (Abrahams and Geschwind, 2008). Because of tissue-specific imprinting, Ube3a is expressed exclusively from the maternal allele in neurons, whereas other tissues

\section{Received April 13, 2011; revised Nov. 30, 2012; accepted Dec. 22, 2012.}

Author contributions: K.H.C., J.H., C.G.R., C.H., and M.D.E. designed research; K.H.C., J.H., C.G.R., and C.H. performed research; K.H.C., J.H., C.G.R., and C.H. contributed unpublished reagents/analytic tools; K.H.C., J.H., C.G.R., and C.H. analyzed data; K.H.C. and M.D.E. wrote the paper.

This work was supported by National Institutes of Health Grants NSO47574 and MHO64748, the Angelman Syndrome Foundation, and the Howard Hughes Medical Institute (M.D.E.). K.H.C. was supported by a fellowship from the Ruth K. Broad Foundation and a National Institutes of Health training grant to the Duke University Department of Neurobiology. We thank John Allen, Tom Helton, Ben Philpot, Joel Schwartz, and Koji Yashiro for helpful discussions and assistance; Richard Weinberg for assistance with electron microscopy; Marguerita Klein for generation of the pGolgi-CFP-YFP construct; Kewa Mou for assistance with embryonic mouse cultures; and John Allen, Juliet Hernandez, Angela Mabb, Tingting Wang, and Jason Yi for insightful discussions and critical comments on the manuscript.

M.D.E. is an employee and shareholder of Pfizer, Inc. The remaining authors declare no competing financial interests.

Correspondence should be addressed to Dr. Michael D. Ehlers, Neuroscience Research Unit, Pfizer, Inc., 700 Main Street, Cambridge, MA 02139. E-mail: michael.ehlers@pfizer.com.

C. G. Robinson's present address is United States Army Medical Research Institute of Infectious Diseases, Pathology Division, Fort Detrick, MD 21702.

C. Hanus' present address is Max Planck Institute for Brain Research, Deutschordenstrasse 46, 60528 Frankfurt, Germany.

DOI:10.1523/JNEUROSCI.1930-11.2013

Copyright $\odot 2013$ the authors $\quad 0270-6474 / 13 / 333799-16 \$ 15.00 / 0$ express Ube3a biallelically (Albrecht et al., 1997; Rougeulle et al., 1997; Dindot et al., 2008; Gustin et al., 2010; Huang et al., 2012). AS model mice $\left(U B E 3 A^{\mathrm{m}-/ \mathrm{p}+}\right)$ have deficits in experiencedependent synaptic plasticity (Jiang et al., 1998; Yashiro et al., 2009; Sato and Stryker, 2010) and synapse development (Dindot et al., 2008; Greer et al., 2010; Wallace et al., 2012), suggesting that Ube3a contributes to neural circuit development and plasticity through mechanisms that remain unclear.

Ube3a has been reported to bind and ubiquitinate diverse substrates (Mabb et al., 2011; Martínez-Noël et al., 2012). These include numerous proteins associated with secretory organelles, especially the Golgi apparatus (GA), such as golgin-160 (Jung et al., 2005), tuberin/TSC2 (Zheng et al., 2008), PIST (Jeong et al., 2007), ubiquilin (Kleijnen et al., 2000), and Src family kinases (Oda et al., 1999). The mammalian GA consists of closely arranged stacks of flat cisternae that sort and process nascent membrane proteins, secreted proteins, and lipids (van Vliet et al., 2003). Despite its stereotyped appearance, GA morphology is dynamic and influenced by many factors (van Vliet et al., 2003). In particular, loss of GA acidification disrupts GA morphology (Tartakoff et al., 1978; Thorens and Vassalli, 1986), impairs processing and glycosylation of proteins and lipids (Thorens and Vassalli, 1986; Palokangas et al., 1994; Rivinoja et al., 2009), and alters cargo sorting (Chanat and Huttner, 1991; Huang and Chang, 2011). Notably, Golgi dysfunction is associated with disorders of brain development and function, including language impairment (Newbury et al., 2009) and epilepsy (Simpson et al., 2004). Whether a functional relationship exists between Ube3a and the GA or other secretory organelles is unknown.

Here we report that cortical neurons of $U B E 3 A^{\mathrm{m}-/ \mathrm{p}+}$ mice display dramatically distended Golgi cisternae in vivo. Using Ube3a knockdown (KD) cell lines and $U B E 3 A^{\mathrm{m}-/ \mathrm{p}+}$ mouse neurons, we demonstrate marked under-acidification of the GA in 
Ube3a-deficient cells. Correspondingly, protein sialylation, a highly $\mathrm{pH}$-dependent process normally occurring in acidic transGolgi cisternae (Thorens and Vassalli, 1986; Axelsson et al., 2001; Rivinoja et al., 2009), is significantly reduced in Ube3a KD cells and Ube3a-deficent mouse cortex. These results define a novel function for Ube3a in maintaining Golgi ion homeostasis and indicate that loss of Ube3a disrupts $\mathrm{pH}$-sensitive functions of the GA. Under-acidification of the GA may contribute to the diverse plasticity and neurodevelopmental deficits reported in $U B E 3 A^{\mathrm{m}-/ \mathrm{p}^{+}}$mice and AS patients.

\section{Materials and Methods}

Mice. Ube3a-deficient mice (129-Ube3a ${ }^{\text {tm1 Alb/Jon }}$ ) on a $129 \mathrm{~Sv} /$ Ev background (Jiang et al., 1998) were obtained from The Jackson Laboratory (Stock \#004477) and housed in a clean facility according to Duke University guidelines and protocols. Ube3a-deficient mice on a C57BL/6 background were obtained from Dr. Arthur Beaudet (Baylor College of Medicine) and Pfizer via The Jackson Laboratory. Maternal heterozygotes were bred with paternal wild-type (WT) mice to obtain $U B E 3 A^{\mathrm{m}-/ \mathrm{p}^{+}}$and WT littermates. Genotyping was performed on ear punch or tail tissue. Genomic DNA was purified using the Genomic DNA Purification Kit (Bio-Rad) or the DNeasy Blood and Tissue Kit (QIAGEN), and PCR was performed using PCR-ready beads (GE Healthcare) with the primer sequences provided by The Jackson Laboratory: $\left(5^{\prime}-3^{\prime}\right)$ common, gct caa ggt tgt atg cct tgg tgc t; WT only, agt tct caa ggt aag ctg agc ttg c; KO only, tgc atc gca ttg tct gag tag gtg tc. Alternatively, genotyping was performed by Transnetyx or The Jackson Laboratory. Differentiation between $U B E 3 A^{\mathrm{m}-/ \mathrm{p}^{+}}$and $U B E 3 A^{\mathrm{m}+/ \mathrm{p}^{-}}$ littermates, when necessary, was performed by immunoblotting from cortical tissue with anti-Ube3a (Bethyl Laboratories).

Electron microscopy. Electron microscopy was performed using brain tissue from 3- to 6-weeks-old (4 WT, $4 U B E 3 A^{\mathrm{m}-/ \mathrm{p}^{+}}, 3 U B E 3 A^{-/-}$) paired 129Sv/Ev mice of either sex. Kidney tissue was also prepared from two additional sets of 4 -week-old mice of either sex. WT and $U B E 3 A^{\mathrm{m}-/ \mathrm{p}^{+}}$mouse pairs were always littermates and prepared in parallel. Deeply anesthetized mice were perfused intracardially with a mixed aldehyde fixative, and the brain removed and postfixed for $2 \mathrm{~h}$ at $4^{\circ} \mathrm{C}$. Vibratome sections $(70 \mu \mathrm{m})$ were collected in phosphate buffer. For one mouse pair, live slices were prepared for electrophysiology as described previously (Yashiro et al., 2009) and fixed with a mixed aldehyde fixative. Vibratome sections were osmicated in phosphate buffer, rinsed in maleate buffer, stained en bloc with uranyl acetate in maleate buffer, and rinsed again in maleate buffer. Sections were dehydrated in serially increasing concentrations of ethanol, transferred to propylene oxide, and infiltrated with EmBed 812 resin. Sections were flat embedded between layers of Aclar plastic and the resin polymerized at $60^{\circ} \mathrm{C}$ for $48 \mathrm{~h}$. Thin sections (70-90 nm) were cut, mounted on copper grids, and contrasted with uranyl acetate and lead salts. Sections were viewed at $80 \mathrm{kV}$ on a FEI Tecnai T20 electron microscope.

Cultured Ube3a KD and scrambled control clone 9 cells were grown on chambered Thermanox slides (Nunc) and fixed, osmicated, stained en $b l o c$, and dehydrated as described previously (Burghardt and Droleskey, 2006). Infiltration was performed with Epon diluted in $100 \%$ ethanol on the chambered slide. After 100\% Epon infiltration, the chamber was removed from the slide, leaving only the sealing gasket. Epon was added to the top of the gasket, and the samples were cured at $60^{\circ} \mathrm{C}$ for $48 \mathrm{~h}$. Unless otherwise specified, all reagents were obtained from Electron Microscopy Sciences.

For GM130 immunolabeling, sections were pretreated in 1\% sodium borohydride and $3 \%$ hydrogen peroxide, blocked in 10\% normal donkey serum, and incubated with anti-GM130 (BD Transduction) overnight in $2 \%$ normal donkey serum. The sections were subsequently incubated with biotin-conjugated donkey anti-mouse IgG (Jackson ImmunoResearch Laboratories) for $2 \mathrm{~h}$, followed by $1 \mathrm{~h}$ in ExtrAvidin-Peroxidase conjugate (Sigma), and finally $10 \mathrm{~min}$ in $\mathrm{Ni}-\mathrm{DAB}$ in hydrogen peroxide. $\mathrm{Ni}-\mathrm{DAB}$ was created by reacting $0.5 \mathrm{mg} / \mathrm{ml} \mathrm{3,3}{ }^{\prime}$-diaminobenzidine with $0.004 \% \mathrm{NH}_{4} \mathrm{Cl}$ and $0.04 \% \mathrm{NiNH}_{4} \mathrm{SO}_{4}$. Labeled sections were then embedded, sectioned, and imaged as above.
Plasmid DNA constructs, cloning, and mutagenesis. Ube3a-pYFP-N1, a gift from Dr. Arthur Beaudet (Baylor College of Medicine), was used for initial screening of shRNA sequences. shRNA sequence \#12894 against Ube3a in a pLKO.1/puro vector was obtained from Sigma as part of the Mission shRNA target kit against mouse E6AP/Ube3a (sense sequence: ccc aat gat gta tga tct aaa), and targets the three known isoforms of $U B E 3 A$ of mouse, rat, and human. Scrambled shRNA in a pLKO.1/puro vector was obtained from Addgene (plasmid \#1864, principal investigator: D. Sabatini). Vesicular stomatitis virus G-protein (VSVGts-GFP) and VAMP2-SEP were gifts from Dr. Kai Simons (Max Planck Institute) and Dr. George Augustine (Korea Institute of Science and Technology), respectively. pGolgi-YFP was created by AgeI/BsrGI digestion of pGolgiCFP and Ube3a-pYFP-N1. pGolgi-CFP was obtained from Addgene (plasmid \#11930, principal investigator: J. Lippincott-Schwartz) as pGolgi-Cerulean. The pGolgi-CFP-YFP construct was created by cloning of PCR-amplified YFP into pGolgi-CFP at the BsrG1 restriction site with a five glycine spacer between CFP and YFP. An endoplasmic reticulum (ER) $\mathrm{pH}$ probe $\mathrm{pER}-\mathrm{CFP}-\mathrm{YFP}$ was created by inserting the BsrG1/BsrG1 YFP fragment from pGolgi-CFP-YFP into pER-CFP (Clontech). Mitochondrial $\mathrm{pH}$ probes pMito-CFP and pMito-YFP were created by ligating the BamHI/NotI digested pDsRed2-Mito (Clontech) and CFP or YFP.

Generation of Ube3a shRNA stable cell line. shRNA sequences were first tested in 293T cells (Duke Tissue Culture Facility, ATCC) by coexpressing them with Ube3a-pYFP-N1 for 1-4 d and analyzing Ube3a KD via immunoblotting for Ube3a. To create stable KD lines, clone 9 cells (Duke Tissue Culture Facility, ATCC) were transfected with Mission shRNA \#12894 (Sigma) against Ube3a or a scrambled shRNA sequence (Addgene plasmid \#1864, principal investigator: D. Sabatini) in a pLKO.1/ puro vector with Lipofectamine 2000 (Invitrogen). After $48 \mathrm{~h}$, cells were treated with $1 \mathrm{mg} / \mathrm{ml}$ puromycin (Invitrogen). Surviving clonal colonies were isolated and analyzed for Ube3a expression levels via immunoblotting for Ube3a (Bethyl Laboratories). Ube3a expression levels in single clones expressing either shRNA against Ube3a or the scrambled shRNA were compared with untreated clone 9 cells. Two clones with consistent Ube3a KD (Ube3a KD, KD2) and one clone with consistent Ube3a expression (control) were selected for further experiments, although other $\mathrm{KD}$ clones with various expression levels were also isolated.

Preparation of cell lysates and immunoblotting. Cells were removed from plates either by trypsinizing or by scraping and rinsed with PBS, pelleted, and used either fresh or frozen at $-80^{\circ} \mathrm{C}$ for later use. Cells were lysed and sonicated in a Tris-Triton X-100 buffer containing $50 \mathrm{~mm}$ Tris, 150 mм NaCl, 2 mм EDTA, 2 mм EGTA, 1\% Triton X-100, pH 7.4, and a mixture of protease and phosphatase inhibitors, including $0.2 \mathrm{~mm}$ PMSF, $1.5 \mathrm{U} / \mathrm{ml}$ aprotinin, $10 \mu \mathrm{g} / \mathrm{ml}$ antipain, $10 \mu \mathrm{g} / \mathrm{ml}$ leupeptin, 10 $\mu \mathrm{g} / \mathrm{ml}$ chymostatin, $10 \mu \mathrm{g} / \mathrm{ml}$ pepstatin, 1:100 Phosphatase Inhibitor Cocktail \#1 (Sigma), and 1:100 Phosphatase Inhibitor Cocktail \#2 (Sigma). Insoluble debris was removed by a $15,000 \times g$ spin at $4^{\circ} \mathrm{C}$ for 10 min. Protein assays were performed on all samples using the DC Protein Assay Kit (Bio-Rad) according to the manufacturer's instructions. Immunoblotting was performed using standard methods with either anti-Ube3a (Bethyl Laboratories), anti- $\beta$-actin (Sigma), anti-tubulin (Sigma), or anti-FLAG M2 (Sigma) primary antibodies, and anti-rabbit or anti-mouse HRP secondary antibodies (Cell Signal). Blots were developed using ECL or ECL Plus (GE Healthcare), imaged using the Black Box imaging system (Fujifilm) and quantified using Multigauge software (Fujifilm).

VSVGts-GFP trafficking assay. Imaging of VSVGts-GFP was performed essentially as described previously (Presley et al., 1997; Horton and Ehlers, 2003). To visualize trafficking from the Golgi, Ube3a KD and scrambled control stable lines were transfected with cDNA encoding VSVGts-GFP using Lipofectamine 2000 (Invitrogen) and incubated at $39.5^{\circ} \mathrm{C}$ overnight. The cells were transferred to $32^{\circ} \mathrm{C}$ to permit forward trafficking of VSVGts-GFP in the presence of $20 \mu \mathrm{g} / \mathrm{ml}$ cyclohexamide. Experiments were also performed with a $3 \mathrm{~h}$ incubation at $20^{\circ} \mathrm{C}$ to accumulate VSVGts-GFP in the GA before the $32^{\circ} \mathrm{C}$ release. Cells were stained live at $4^{\circ} \mathrm{C}$ with an antibody directed toward the lumenal $\mathrm{N}$-terminal domain of VSVG (Dr. Kai Simons, Max Planck Institute) without permeabilization. Cells were subsequently fixed and costained with DAPI 
and anti-mouse Alexa-647 (Invitrogen). Coverslips were imaged on an Ultraview spinning disk confocal microscope (PerkinElmer). VSVGtransfected cells were traced using MetaMorph and ImageJ analysis software, background subtracted, and average intensities of the anti-VSVG (647) and VSVGts-GFP signals were measured.

VAMP2-SEP trafficking. The rate of dendritic exocytic events of VAMP2-SEP was used to measure cargo exit from the GA (Cui-Wang et al., 2012). UBE3A ${ }^{\mathrm{m}-/ \mathrm{p}+}$ and WT cultured cortical neurons were transfected with VAMP2-SEP and imaged live $\sim 20-28 \mathrm{~h}$ later in E4 imaging solution (120 mm NaCl, $3 \mathrm{~mm} \mathrm{KCl}, 10 \mathrm{~mm}$ HEPES, $2 \mathrm{~mm} \mathrm{CaCl}_{2}, 2 \mathrm{~mm}$ $\mathrm{MgCl}_{2}, 2 \mathrm{~mm} \mathrm{NaHCO}, 10 \mathrm{~mm}$ glucose, $\mathrm{pH} 7.4$ ) at $36^{\circ} \mathrm{C}$ on a spinning disk confocal microscope (Nikon). Single planes were imaged for 5-12 min (mean $8.8 \mathrm{~min}$ ) at $0.2 \mathrm{~Hz}$. As a control, $50 \mathrm{mM} \mathrm{NH}_{4} \mathrm{Cl}$ in $\mathrm{E} 4$ was added at the end of some imaging sessions to reveal VAMP2-SEP in intracellular, normally acidic compartments. For analysis, proximal dendritic sections (maximum three per neuron) were blindly selected. Individual exocytic events were counted manually and blind to genotype, identified by their transient appearance. Event rate was calculated as $\mathrm{N}_{\text {events }} \times \min ^{-1} \times \mu \mathrm{m}^{-1} \times 100$, with each data point representing one neuron.

Golgi, ER, mitochondrial, and cytoplasmic pH measurements. To measure Golgi $\mathrm{pH}$, cells were dually transfected with pGolgi-YFP and pGolgiCFP (Llopis et al., 1998) using Lipofectamine 2000 (Invitrogen). Between 22 and $27 \mathrm{~h}$ later, cells were imaged live on an Ultraview spinning disk confocal microscope (PerkinElmer) in either E4 imaging solution or MES pH calibration buffer ( $115 \mathrm{~mm} \mathrm{KCl,} 5 \mathrm{~mm} \mathrm{NaCl}, 1.2 \mathrm{~mm} \mathrm{MgSO}_{4}, 25$ mM MES, $10 \mu \mathrm{M}$ monensin, $0.5 \mu \mathrm{M}$ bafilomycin A1; 20 min incubation before imaging). For analysis, the pGolgi-CFP signal was traced using a color-combined image, and the average intensity for pGolgi-YFP and pGolgi-CFP was then calculated for each imaged cell after background subtraction. Golgi $\mathrm{pH}$ measurements in neurons were performed using the same method after expression of the pGolgi-CFP-YFP probe, which was first tested in 293T cells incubated under various $\mathrm{pH}$ conditions in MES $\mathrm{pH}$ calibration buffer to ensure a linear $\mathrm{pH}$ reading between $\mathrm{pH} 5$ and $\mathrm{pH}$ 7.5. Relative $\mathrm{ER} \mathrm{pH}$ and mitochondrial $\mathrm{pH}$ in $U B E 3 A^{\mathrm{m}-/ \mathrm{p}+}$ and WT cultured neurons were measured with analogous methods using the pER-CFP-YFP and pMito-YFP plus pMito-CFP probes described above.

The membrane-permeable $\mathrm{pH}$-sensitive dual-emission dye carboxy SNARF1 acetoxymethyl ester acetate (Invitrogen) was used to measure cytoplasmic $\mathrm{pH}$ (Han and Burgess, 2010). This dye is excited at $488 \mathrm{~nm}$, and the relative intensities of red $(548-595 \mathrm{~nm})$ and far red $(620-650 \mathrm{~nm})$ emission are $\mathrm{pH}$-dependent (Han and Burgess, 2010). $U B E 3 A^{\mathrm{m}-/ \mathrm{p}^{+}}$and WT cortical neurons were incubated with $10 \mu \mathrm{M}$ SNARF1 for $15-25 \mathrm{~min}$ at $37^{\circ} \mathrm{C}$, washed in $\mathrm{E} 4$, and subsequently imaged live on a Leica laser scanning confocal microscope. To calibrate the dye, WT neurons were incubated in $\mathrm{pH}$-calibrated buffers ( $\mathrm{pH}$ 6.40, $\mathrm{pH} 7.06, \mathrm{pH} 7.60$, and $\mathrm{pH} 8.14$; containing $115 \mathrm{~mm} \mathrm{KCl,} 5$ mм NaCl, $1.2 \mathrm{~mm} \mathrm{MgSO}_{4}, 25 \mathrm{~mm}$ HEPES, $10 \mu \mathrm{m}$ nigericin, $10 \mu \mathrm{M}$ SNARF1) for 15-25 min before imaging. For analysis, stacks were maximum-projected, and mean intensity was measured for the same somatic regions on both red and far red channels. The background fluorescence values were subtracted from these results and the ratio of Red:Far Red fluorescence per cell was determined.

Primary mouse neuronal cultures. Primary neuronal cultures were derived from early postnatal or embryonic mouse pups of either sex from both 129SvEv and C57BL/6 litters. Cortices were individually dissected in dissection media: 0.3\% BSA (Invitrogen), $12 \mathrm{~mm} \mathrm{MgSO}_{4}$ (Sigma), $10 \mathrm{~mm}$ HEPES (Invitrogen), 0.6\% glucose (Sigma), and $10 \mu \mathrm{g} / \mathrm{ml}$ gentamicin (Invitrogen) in HBSS (Invitrogen). Neurons were dissociated, suspended in dissection media, and triturated. Cells from each pup were plated at high density onto poly-D-lysine-coated coverslips in Neurobasal medium (Invitrogen) supplemented with 5\% FBS (Hyclone), 2\% B27 (Invitrogen), $2 \mathrm{~mm}$ Glutamax (Invitrogen), and $1 \mu \mathrm{g} / \mathrm{ml}$ gentamicin (Invitrogen). Before transfection, the media was changed to maintenance medium: 2\% B27, 2 mm Glutamax, 10 mm FUDR (Sigma) in Neurobasal. Cells were maintained at $37^{\circ} \mathrm{C}$ and $5 \% \mathrm{CO}_{2}$. Genotyping was performed after plating as above on tail tissue and by immunoblot using remaining cortical cells. All experiments using cultured cortical neurons were performed between 7 and 14 DIV.
Lectin staining. Coverslips were fixed in 4\% paraformaldehyde/4\% sucrose in Dulbecco's PBS (dPBS) for $20 \mathrm{~min}$ at room temperature and washed with dPBS. Sambucus nigra (SNA)-fluorescein (Vector Laboratories) was diluted 1:200 in $\mathrm{dPBS}$ and heated to $37^{\circ} \mathrm{C}$, sonicated, and spun to remove precipitates. Coverslips were incubated with $200 \mu \mathrm{l}$ of lectin solution for $30 \mathrm{~min}$ at room temperature in the dark, washed, costained with DAPI (Invitrogen), and mounted onto slides. The specificity of SNA-fluorescein for labeling of sialylconjugates was demonstrated by treating the fixed cells with 1:100 neuraminidase in G1 buffer (New England Biolabs) overnight at $37^{\circ} \mathrm{C}$ before lectin staining. Alternatively, cells were scraped from plates and lysates were prepared as above for immunoblotting. Membranes were subsequently incubated with 1:3000 SNA-HRP (EY Laboratories) for $\sim 1 \mathrm{~h}$ at room temperature and developed with ECL (GE Healthcare). For analysis, ImageJ was used to measure the integrated band intensity of SNA-reactive sialylconjugates $>50 \mathrm{kDa}$. Each Ube3a KD sample was compared with the corresponding control sample on the same blot.

Isolation of surface proteins containing synthetic sialic acid residues. Tissue culture plates were coated with acetylated $\mathrm{N}$-azidoacetylmannosamine (Sig$\mathrm{ma} ; 1 \mathrm{mg} / 8 \mathrm{ml}$ of EtOH) or EtOH alone (negative control) and allowed to dry. Ube $3 \mathrm{a} \mathrm{KD}$ and scrambled control cells were plated onto the coated dishes and allowed to grow for $72 \mathrm{~h}$. The media from one plate per condition was removed and replaced with 1:100 neuraminidase (New England Biolabs) in $\mathrm{dPBS}$ and incubated for $30 \mathrm{~min}$ at $37^{\circ} \mathrm{C}$. Cells from all conditions were then washed in dPBS, scraped, and pelleted. Cells were resuspended in Glycoprofile FLAG-Phosphine conjugate (Sigma; $1 \mathrm{mg} / 2.96 \mathrm{ml}$ of dPBS) and rotated overnight at $4^{\circ} \mathrm{C}$. FLAG-phosphine reacted cells were lysed in Tris-Triton X-100 lysis buffer, sonicated, and debris removed by centrifugation. Equal protein amounts from each condition were boiled in the presence of DTT. FLAG-tagged proteins were then isolated by immunoprecipitation with $1 \mu \mathrm{l}$ of mouse anti-FLAG antibody (Sigma M2) overnight at $4^{\circ} \mathrm{C}$ and isolated by subsequent addition of $30 \mu \mathrm{l}$ of Ultralink Protein A/G Agarose Beads for $1 \mathrm{~h}$ at $4^{\circ} \mathrm{C}$. Precipitated beads were washed with Tris-Triton X-100 buffer, boiled in $30 \mu$ l of $5 \times$ Laemmli buffer for $5 \mathrm{~min}$, and proteins resolved by SDS-PAGE. The resulting membranes were blocked with $4 \%$ BSA, incubated with mouse anti-FLAG (Sigma M2) overnight at $4^{\circ} \mathrm{C}$ and then with HRP-conjugated anti-mouse secondary antibody (Cell Signal). Membranes were developed using either ECL or ECL Plus (GE Healthcare) and the Fujifilm Smart Black Box image detection system. Intensity of all bands above the IgG signal per condition were quantified using Multigauge software (Fujifilm).

Protein sialylation in $U B E 3 A^{-1-}$ cortex. Cortices from 11- to 15 -weeks old $U B E 3 A^{-I-}$ and WT C57BL/6 mice of either sex were rapidly isolated, flash frozen on dry ice, homogenized in a HEPES-sucrose buffer (4 mM HEPES, $0.32 \mathrm{~m}$ sucrose, and protease inhibitor mixture tablets, Roche) and prepared for SDS-PAGE as above. Equal amounts of protein per sample were loaded onto gels, transferred onto membranes, and blocked with Carbo-Free Blocking Buffer (Vector Laboratories). To probe with multiple lectins/antibodies, sample sets were run in parallel on multiple gels or stripped and reprobed. Blots were incubated with SNA-HRP (EY Laboratories; no subsequent secondary), anti-Ube3a (Sigma, anti-mouse secondary from Pierce), or anti-GAPDH (Sigma, anti-mouse secondary from Pierce), and developed using ECL Plus (GE Healthcare) and GelDoc (Bio-Rad) systems. As a control for lectin reactivity, WT cortical lysates were pretreated with $0.5 \mu \mathrm{l}$ of neuraminidase per $100 \mu \mathrm{g}$ of lysate (New England Biolabs) for $3 \mathrm{~h} 20 \mathrm{~min}$ at $37^{\circ} \mathrm{C}$. For analysis, ImageJ was used to measure the integrated band intensity of SNA-reactive sialylconjugates $>75 \mathrm{kDa}$. Each $U B E 3 A^{-1-}$ sample was compared with the adjacent WT sample.

Statistics. All data shown represent mean \pm SEM. For imaging experiments, measurements from a sufficient number of cells per coverslip were averaged to represent the mean for an individual experiment. Twotailed Student's $t$ tests were used to compare two experimental means. One-way ANOVAs were performed to determine whether significant differences existed among multiple means. 


\section{Results}

Golgi cisternae are severely distended in $U B E 3 A^{\mathrm{m}-/ \mathrm{p}^{+}}$and UBE $3 A^{-/-}$mouse cortex

To examine the effect of loss of Ube3a on organelle structure, we performed electron microscopy on WT, $U B E 3 A^{\mathrm{m}-/ \mathrm{p}+}$, and $U B E 3 A^{-1-}$ mouse visual cortex, a brain region where $U B E 3 A$ is imprinted and its absence leads to deficits in experiencedependent plasticity (Yashiro et al., 2009; Sato and Stryker, 2010). In contrast to the typical organization of compact, stacked cisternae in WT neurons (Fig. $1 A, B$, white arrows), the GA in $U B E 3 A^{\mathrm{m}-/ \mathrm{p}^{+}}$and $U B E 3 A^{-1-}$ neurons exhibited swollen, distended, and disorganized cisternae (Fig. $1 C-F$ ). Although cisternal swelling disrupted GA morphology, the Golgi stack arrangement was preserved in $U B E 3 A^{\mathrm{m}-/ \mathrm{p}^{+}}$and $U B E 3 A^{-1-}$ brain with swollen membranes frequently observed adjacent to normal narrow cisternae (Fig. $1 C, D, F$, black arrows). Immunolabeling with the cis-Golgi marker GM130 confirmed the identity of the GA (Fig. 1B,D,F). GM130 immunoreactivity localized to slightly distended membranes adjacent to the most severely swollen compartments (Fig. 1D,F), although cisternal swelling was not obviously restricted to any particular Golgi subcompartment.

In contrast to Golgi abnormalities seen in neurodegenerative disorders (Gonatas et al., 2006), the GA in $U B E 3 A^{\mathrm{m}-/ \mathrm{p}^{+}}$or $U B E 3 A^{-1-}$ mice was not highly fragmented or dispersed. Moreover, whereas the morphological integrity of the GA was disrupted in the $U B E 3 A^{\mathrm{m}-/ \mathrm{p}+}$ brain, the ER and nuclear membrane were structurally intact and indistinguishable from WT (Fig. 2A). We also examined Golgi structures in kidney, where Ube3a is biallelically expressed (Fig. 2B). Despite moderately reduced Ube3a levels in $U B E 3 A^{\mathrm{m}-/ \mathrm{p}^{+}}$kidney, GA morphology was indistinguishable from WT (Fig. 2C). However, much like $U B E 3 A^{\mathrm{m}-/ \mathrm{p}+}$ cortex, the GA in $U B E 3 A^{-/-}$kidney contained swollen cisternae (Fig. 2C), suggesting that complete loss of Ube3a contributes to GA pathology in multiple tissues. Together, these data show that loss of Ube3a leads to a severe and selective disruption of Golgi morphology in vivo that is characterized by swelling and distension of Golgi cisternae.

\section{Ube3a KD cells have disrupted Golgi}

The GA in mammalian cells is organized into characteristic stacks of narrow membrane-bound structures, and maintenance of this morphology is dependent on a number of cellular processes (van Vliet et al., 2003). In particular, Golgi cisternae become enlarged and distended during inhibition of cargo trafficking (Griffiths et al., 1989; Ladinsky et al., 2002; Cao et al., 2005) or elevation of the normally acidic intralumenal pH (Ledger et al., 1980; Thorens and Vassalli, 1986; Kellokumpu et al., 2002; Lázaro-Diéguez et al., 2006). Although methods to examine Golgi trafficking and $\mathrm{pH}$ in the intact brain in vivo are lacking, assays for both cargo trafficking (Presley et al., 1997; Lippincott-Schwartz et al., 2000; Horton and Ehlers, 2003; Sampo et al., 2003; Horton et al., 2005; CuiWang et al., 2012) and Golgi pH (Llopis et al., 1998; Paroutis et al., 2004) have been extensively developed for cultured cells. To test for defects in Golgi function in the absence of Ube3a, we created clonal cell lines with stable RNAi KD of Ube3a (Fig. $3 A, B$; Ube3a level normalized to nontransfected control cells: Ube3a $\mathrm{KD} 18.1 \pm 4.5 \%, p<0.001, n=12$; KD2 $21.1 \pm 9.6 \%, p=0.001$, $n=5$; scrambled control $84.6 \pm 13.3 \%, p=0.30, n=6)$. Given reports of altered Golgi structure and function in some cancer cell lines (Egea et al., 1993; Kellokumpu et al., 2002; Rivinoja et al., 2006), we chose clone 9 cells, a rat normal liver cell line that is not tumorigenic (Weinstein et al., 1975). As with $U B E 3 A^{\mathrm{m}-/ \mathrm{p}^{+}}$neurons in vivo, ultrastructural examination revealed disrupted GA morphology in Ube3a KD cells compared with scrambled RNAi control cells (Fig. 3C,D). Knockdown of Ube3a resulted in rounded, swollen Golgi cisternae that were often fenestrated (Fig. 3D). The GA morphology phenotype in Ube3a KD cells was less severe than $U B E 3 A^{\mathrm{m}-/ \mathrm{p}^{+}}$neurons in vivo (Fig. 1) potentially because of differences in cell type or residual Ube3a expression. As there were no obvious effects of Ube3a KD on cell proliferation, the Golgi phenotype is not likely the result of cell cycle disruption, a notion further supported by the disrupted GA morphology in postmitotic neurons (Fig. 1). Together, these findings demonstrate that altered Golgi morphology caused by loss of Ube3a is not specific to neurons and is not the result of prolonged lack of Ube3a over development. In addition, these results indicate that Ube3a KD cells can serve as a model system for Ube3adependent regulation of the GA.

\section{Generalized secretory trafficking is not compromised in Ube3a KD cells or $U B E 3 A^{\mathrm{m}-/ \mathbf{p}^{+}}$neurons}

Nascent membrane proteins are synthesized at the ER, processed and sorted in the GA, and trafficked to their final destination via post-Golgi carriers (Lippincott-Schwartz et al., 2000; van Vliet et al., 2003; Hanus and Ehlers, 2008). Disruption of trafficking to, from, or within the GA can result in the distortion of Golgi morphology (Griffiths et al., 1989; Ladinsky et al., 2002; Cao et al., 2005). We thus tested whether altered secretory trafficking through the GA could explain the distended Golgi morphology in cells lacking Ube3a. For this, we exploited the ts045 temperaturesensitive mutant of the VSVGts-GFP, a model cargo protein that has been extensively used to visualize cargo transport through the secretory pathway (Presley et al., 1997; Lippincott-Schwartz et al., 2000). VSVGts-GFP is retained in the ER at $39.5^{\circ} \mathrm{C}$ and released upon a switch to $32^{\circ} \mathrm{C}$, allowing synchronized release of a bolus of fluorescent cargo from the ER that can be visualized during transport to the GA and the plasma membrane (Presley et al., 1997; Horton and Ehlers, 2003). Using this strategy, we monitored VSVGts-GFP trafficking through the GA and accumulation at the plasma membrane after release from the ER (see Materials and Methods). Surprisingly, we observed no difference in the transport of VSVGts-GFP from the ER to the plasma membrane via the GA between control cells and Ube3a KD cells (Fig. 4A,B). Moreover, using surface immunolabeling to measure VSVGtsGFP accumulation at the plasma membrane after release from the ER, we found that the kinetics of membrane accumulation were unaffected by loss of Ube3a (surface/total VSVG: control, 0 $\min 0.39 \pm 0.12,30 \min 1.93 \pm 0.24,60 \min 2.99 \pm 0.31$; Ube3a $\mathrm{KD}, 0 \min 0.27 \pm 0.04,30 \min 2.30 \pm 0.24,60 \min 3.14 \pm 0.39$; $n=7$ or $8 ; p>0.2$ at all time points; Fig. $4 A-C$ ). To selectively monitor post-Golgi secretory trafficking, we introduced a second temperature block at $20^{\circ} \mathrm{C}$ to accumulate VSVGts-GFP in the GA before cargo release (Presley et al., 1997; Horton et al., 2005). Using this paradigm, we observed no difference in VSVGts-GFP surface accumulation after release from Golgi retention (surface/ total VSVG, 30 min: control $2.47 \pm 0.38$, Ube3a KD $2.06 \pm 0.34$; $n=4$ or $5 ; p=0.46$ ).

We next measured the trafficking rate of newly synthesized VAMP2, a protein that mediates presynaptic vesicle endocytosis (Schoch et al., 2001), in UBE3A ${ }^{\mathrm{m}-/ \mathrm{p}+}$ and WT cortical neurons (Fig. $4 D-H$ ). VAMP2 is indirectly targeted to the axonal compartment via transcytosis (Sampo et al., 2003; Winckler, 2004; Lasiecka and Winckler, 2011). Upon leaving the Golgi, VAMP2 is first trafficked into dendrites, where it is exocytosed at the plasma membrane (Sampo et al., 2003). VAMP2 is then rapidly endocytosed and retrafficked to the axon, where it accumulates at axonal 


\section{A Wildtype}

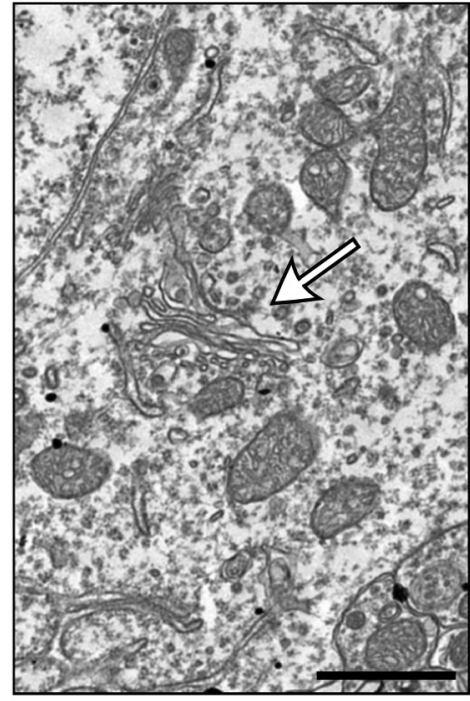

\section{UBE3A $A^{\mathrm{m}-1 \mathrm{p}+}$}

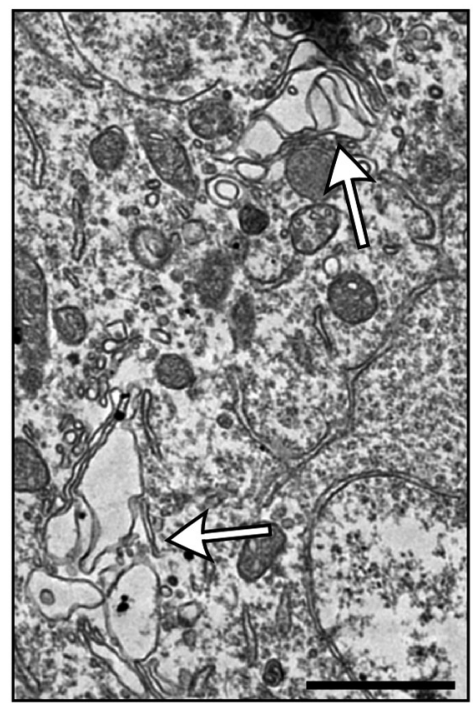

\section{E UBE3A}

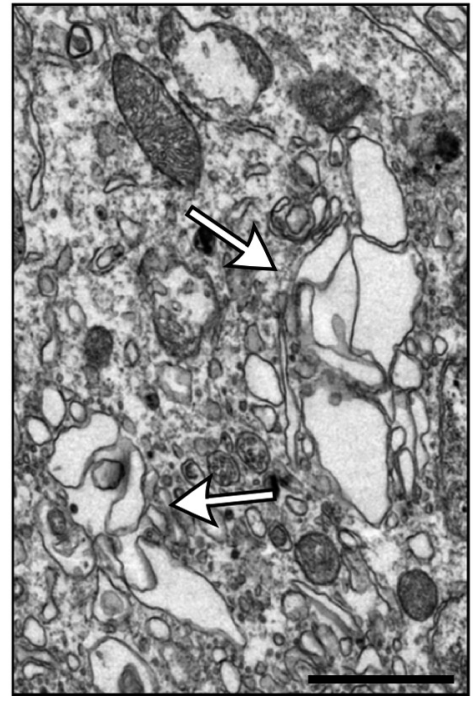

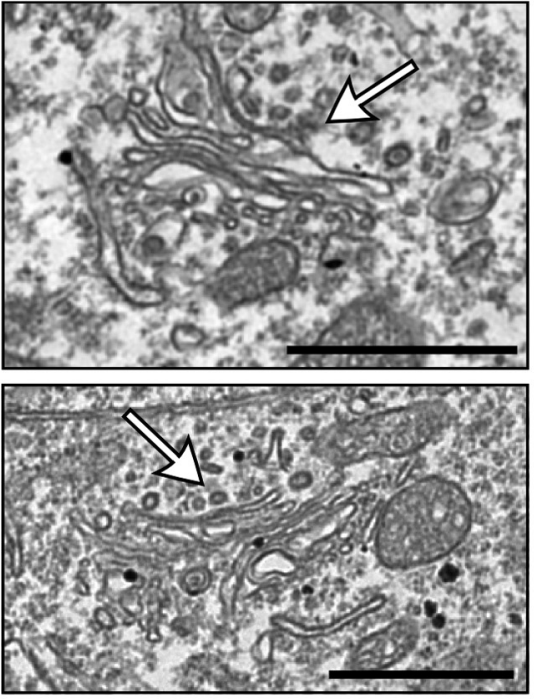
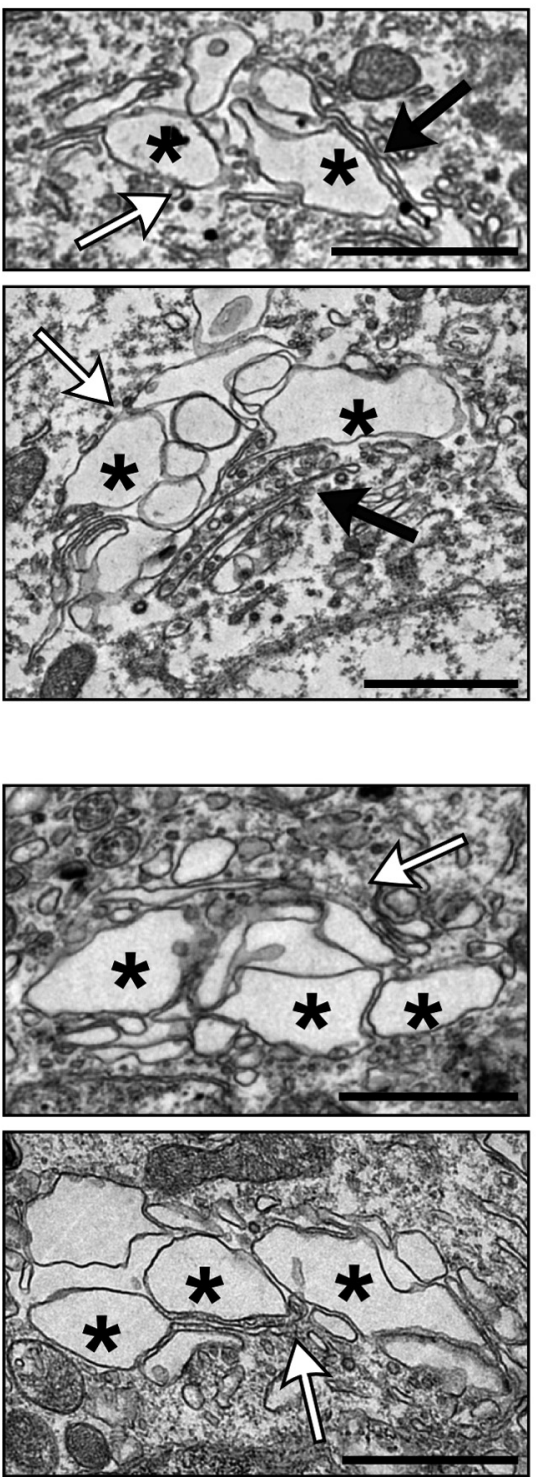

B Wildtype
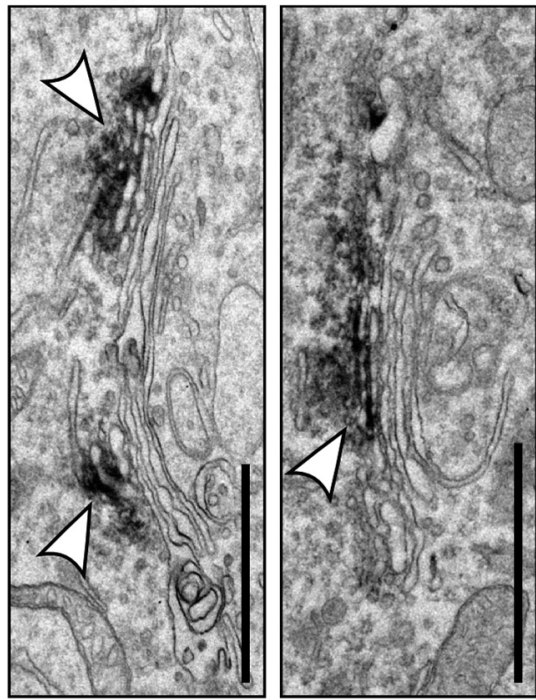

DUBE3A $A^{\mathrm{m}-/ \mathrm{p}+}$
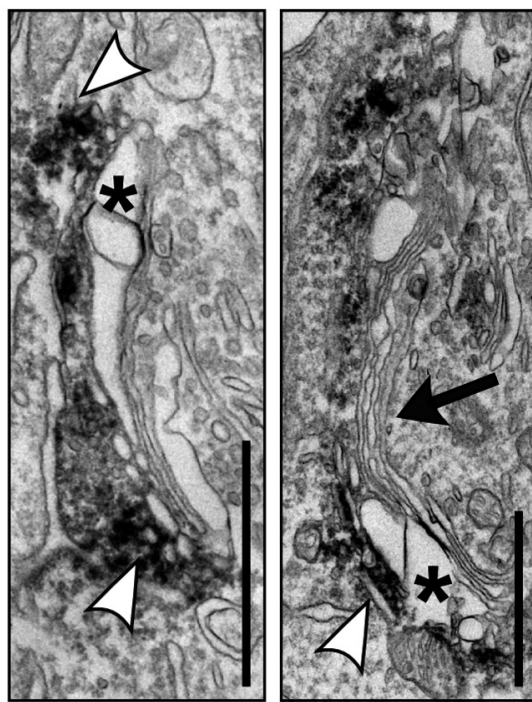

\section{F UBE3A-}

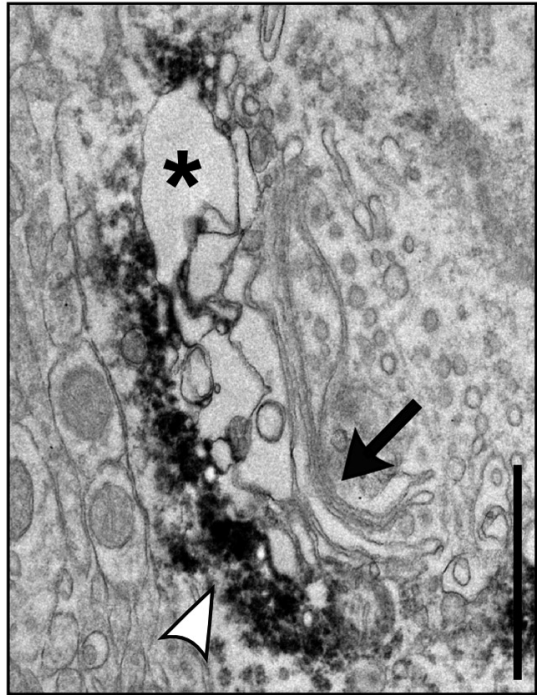

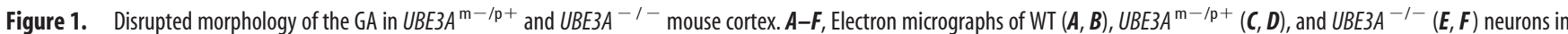
primary visual cortex. The GA (white arrows) of WT neurons has tightly stacked cisternae with narrow intralumenal spaces arranged in stacked arrays. In contrast, the (Figure legend continues.) 
terminals (Sampo et al., 2003). Thus, despite its predominantly presynaptic localization, the trafficking route of newly synthesized VAMP2 allows direct imaging of the secretory exocytosis of a naturally occurring cargo at the somatodendritic membrane (Sampo et al., 2003; Cui-Wang et al., 2012) (Fig. 4D), and hence, an indirect assessment of cargo exit from the GA.

To monitor exocytic events, VAMP2 was tagged with superecliptic pHluorin, a pH-sensitive fluorophore that is quenched at the acidic $\mathrm{pH}$ of intracellular compartments but fluoresces at the neutral pH of the extracellular space (Miesenböck et al., 1998; Kennedy et al., 2010). Discrete exocytic events in live VAMP2SEP transfected neurons were identified by their transient flash-like appearance (Fig. $4 E, F$ ). These abrupt increases in VAMP2-SEP fluorescence upon exocytosis were readily detectable in $U B E 3 A^{\mathrm{m}-/ \mathrm{p}+}$ and WT dendrites, indicating that the postGolgi carriers are acidified relative to the extracellular media in both cases. The number of events $(N)$ per minute were counted and normalized to the dendritic length to calculate the exocytic event rate. There was no significant difference in the exocytic event rate between $U B E 3 A^{\mathrm{m}-/ \mathrm{p}^{+}}$and WT neurons $\left(N \times \min ^{-1} \times \mu \mathrm{m}^{-1} \times 100\right.$ : WT $0.459 \pm 0.13, n=13$ neurons; $U B E 3 A^{\mathrm{m}-/ \mathrm{p}+} 0.681 \pm 0.15, n=9 ; p=0.28$; Fig. $4 G$ ). In agreement with our results in Ube3a KD cells, these data show that there is not a generalized inhibition of cargo exit from the GA in the absence of Ube3a. Thus, GA distension in AS model mice and cells is not caused by a block of constitutive secretory cargo exit.

\section{Under-acidification of the GA in the absence of Ube3a}

Distended Golgi cisternae can also arise from disruptions in Golgi osmolarity and intralumenal pH (Ledger et al., 1980; Thorens and Vassalli, 1986; Kellokumpu et al., 2002; Lázaro-Diéguez et al., 2006). We thus sought to determine whether the normally acidic $\mathrm{pH}$ of the Golgi lumen (Paroutis et al., 2004; Casey et al., 2010) is altered in cells lacking Ube3a. To measure GA intralumenal $\mathrm{pH}$ in live cells, we exploited the $\mathrm{pH}$ sensitivity of YFP and the relative $\mathrm{pH}$ insensitivity of CFP. Specifically, we directed these fluorescent proteins to the lumen of medial/trans-Golgi cisternae by fusion with the Golgi targeting domain of $\beta$-1,4-galactosyltransferase. Because of the

$\leftarrow$

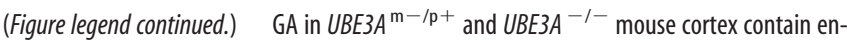
larged and distended cisternae (asterisks), often adjacent to cisternae with normal morphology (black arrows). $\boldsymbol{B}, \boldsymbol{D}, \boldsymbol{F}, \mathrm{GM} 130$ immunoreactivity (electron-dense DAB precipitates, white arrowheads) marking the cis-Golgi in WT $(\boldsymbol{B}), U B E 3 A^{\mathrm{m}-/ \mathrm{p}+}(\boldsymbol{D})$, and UBE3A $A^{-1-}(\boldsymbol{F})$ neurons of visual cortex. Scale bars, $1 \mu \mathrm{m}$.
A

Wildtype
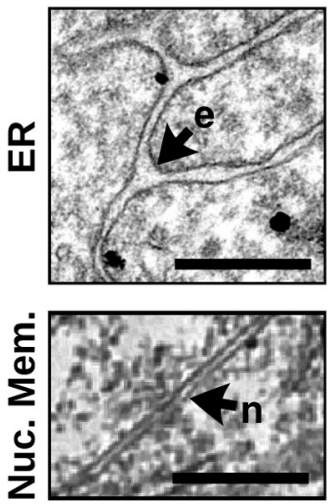

B

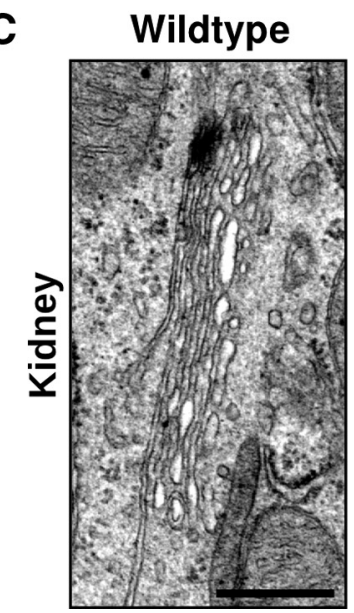

$U B E 3 A^{\mathrm{m}-\mathrm{p}+}$

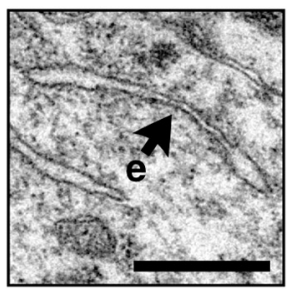

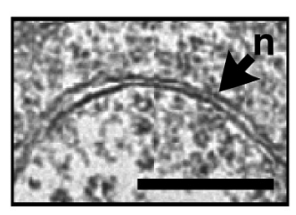

UBE3A ${ }^{-1-}$
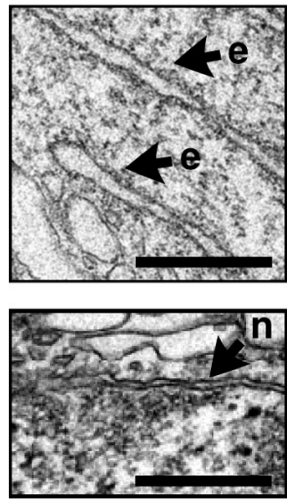

Figure 2. Gross alteration of organellar ultrastructure is limited to the GA and to tissues lacking Ube3a. $\boldsymbol{A}$, Comparable morphologies of the peripheral ER (e) and nuclear envelope $(\mathrm{n})$ in visual cortical neurons from WT, $U B E 3 A^{\mathrm{m}-/ \mathrm{p}+}$, and UBE3A $A^{-1-}$ mice. Scale bars, $500 \mathrm{~nm}$. $\boldsymbol{B}$, Immunoblot analysis of Ube3a expression in brain and kidney of WT, UBE3 $A^{\mathrm{m}-/ \mathrm{p}+}$, and $U B E 3 A^{-1-}$ mice. $C$, Electron micrographs of GA in WT, UBE3 $A^{\mathrm{m}-/ \mathrm{p}+}$, and $U B E 3 A^{-1-}$ kidney. There is GA swelling in $U B E 3 A^{-1-}$ kidney (asterisk) and unaltered GA morphology in UBE3 $A^{\mathrm{m}-/ \mathrm{p}+}$ kidney. Scale bars, $500 \mathrm{~nm}$.

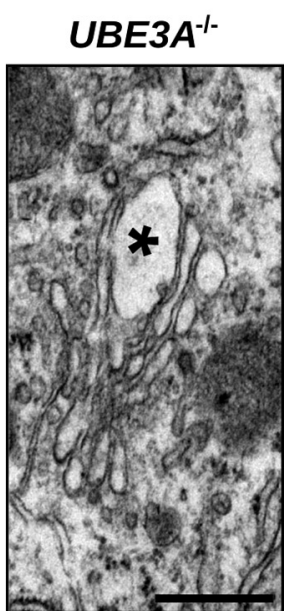

quenching of YFP by low $\mathrm{pH}$, the ratio of YFP to CFP fluorescence in individual live cells provides a measure of intralumenal Golgi pH (Fig. 5A,B) (Llopis et al., 1998). To obtain an absolute measure of intralumenal Golgi $\mathrm{pH}$, we calibrated the YFP:CFP fluorescence intensity ratios to measurements obtained under defined $\mathrm{pH}$ conditions (Fig. $5 \mathrm{C}$ ). In Ube3a $\mathrm{KD}$ cells, the GA pH was significantly elevated compared with control cells (control, pH $5.9 \pm 0.1$; Ube3a KD $7.2 \pm 0.1 ; n=14 ; p<0.001$; Fig. $5 D, E$ ). In independent experiments, Golgi $\mathrm{pH}$ was elevated in another Ube3a KD clonal cell line tested as indicated by an increase in the YFP:CFP ratio (YFP/CFP: control $1.23 \pm 0.10$; Ube3a KD2 $1.73 \pm 0.14, p=0.01 ; n=11$ or 12$)$. The measured intralumenal $\mathrm{pH}$ in control cells $(\mathrm{pH} 5.9 \pm 0.1)$ was consistent with values reported previously, which range between $\mathrm{pH} 5.9$ and $\mathrm{pH}$ 6.6, depending on cell type and cis- versus trans-Golgi (Kim et al., 1996; Seksek et al., 1996; Llopis et al., 1998; Farinas and Verkman, 
A

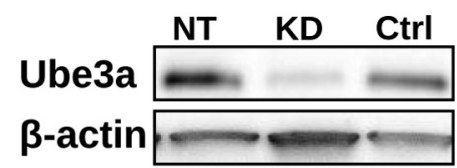

B

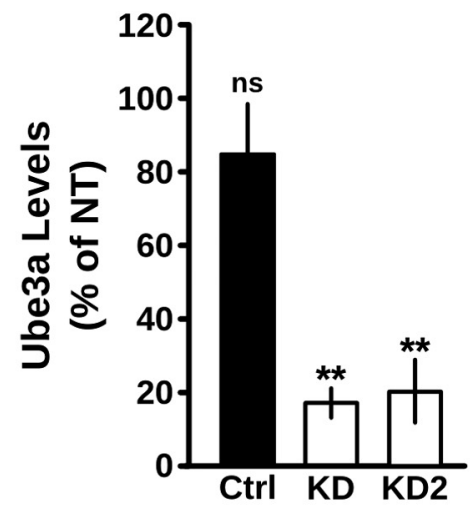

C

\section{Control}
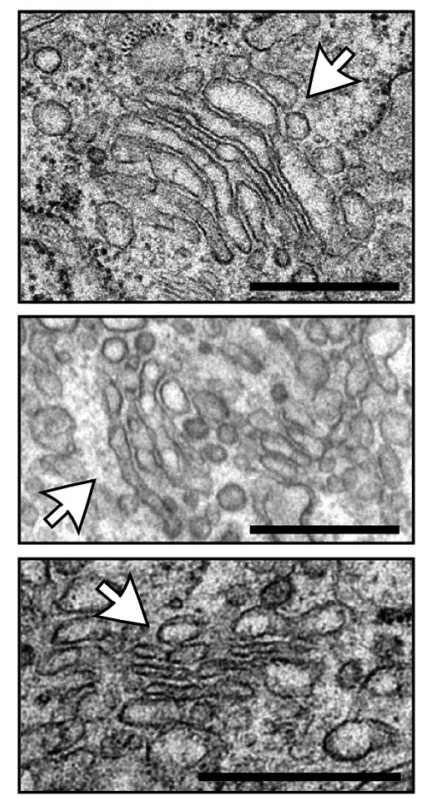

D

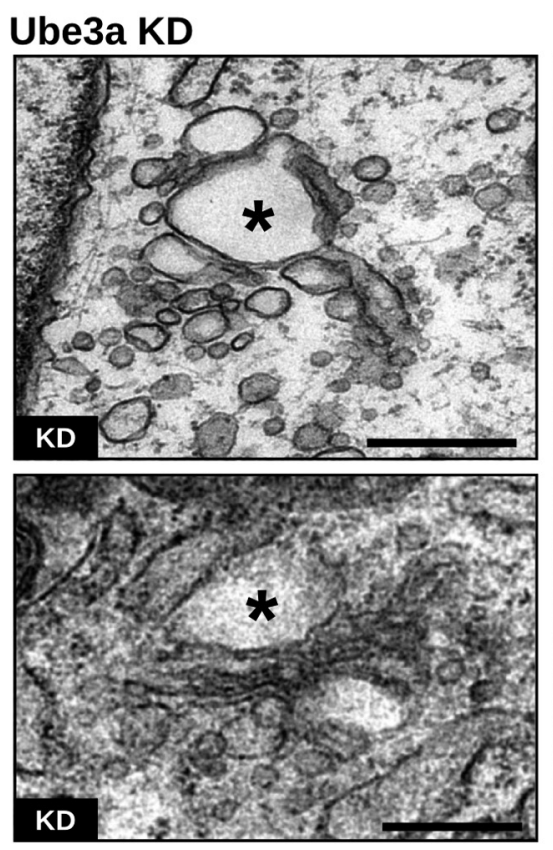

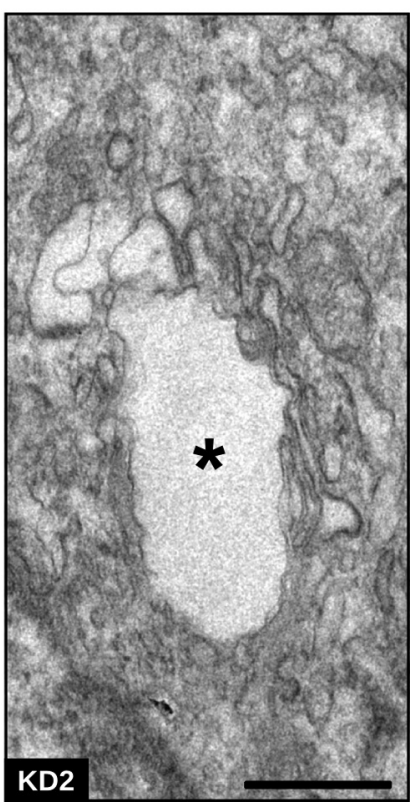

Figure 3. Ube3a KD disrupts Golgi morphology. A, Knockdown of endogenous Ube3a in clone 9 cells stably expressing Ube3a shRNA. NT, Nontransfected cells; KD, KD cells stably expressing shRNA against Ube3a; Ctrl, cells stably expressing a nontargeting scrambled shRNA. B, Quantification of Ube3a levels in scrambled control (Ctrl) and Ube3a KD cells, clones KD and KD2, relative to nontransfected (NT) clone 9 cells. ${ }^{* *} p \leq 0.001$. ns, Not significant $(p=0.30)$. C, $\boldsymbol{D}$, Electron micrographs of GA in $(\boldsymbol{C}$ ) control cells stably expressing scrambled shRNA and (D) stable Ube3a KD cells clones KD and KD2. The GA in control cells have narrow, elongated cisternae arranged in a characteristic stacked structure (white arrows). In contrast, Golgi cisternae in Ube3a KD cells are swollen (asterisks) and disorganized. Scale bars, $500 \mathrm{~nm}$.

1999; Schapiro and Grinstein, 2000; Maeda et al., 2008). In contrast, the neutralized Golgi pH in Ube3a KD cells was substantially higher than any reported values in unperturbed cells.

To further examine the role of Ube3a in Golgi acidification and to test whether altered Golgi $\mathrm{pH}$ contributes to neuronal dysfunction in AS, we measured Golgi $\mathrm{pH}$ in cortical neurons cultured from $U B E 3 A^{\mathrm{m}-/ \mathrm{p}^{+}}$mice. In cell lines, high levels of transfection permitted the use of population analysis to overcome variability in the expression rates of our YFP and CFP Golgi probes. In contrast, much lower efficiency transfection rates were expected in primary neuron cultures from postnatal mice. Therefore, we generated a dual-tagged pGolgi-CFP-YFP construct (Fig. $5 F$ ) to decrease transfection variability. We first tested this probe in 293T cells, which again revealed a linear relationship between $\mathrm{pH}$ and the YFP:CFP fluorescence ratio (YFP/CFP: $\mathrm{pH} 5.0$, $\left.0.20 \pm 0.02 ; \mathrm{pH} 6.0,0.65 \pm 0.05 ; \mathrm{pH} 7.0,1.1 \pm 0.10, R^{2}=0.999\right)$. These results demonstrate that any interactions between the fluorophores did not diminish the probe's ability to report Golgi $\mathrm{pH}$. In agreement with our results from Ube3a KD cell lines,
$U B E 3 A^{\mathrm{m}-/ \mathrm{p}^{+}}$neurons had significantly elevated intralumenal Golgi $\mathrm{pH}$ as indicated by an increase in YFP:CFP ratio (YFP/CFP, normalized to WT: WT $1.0 \pm 0.10, U B E 3 A^{\mathrm{m}-/ \mathrm{p}+} 1.74 \pm 0.19$; $n=4$ or $5 ; p=0.001$, Fig. $5 G, H)$. Together, these results strongly suggest that loss of Ube3a results in the elevation of Golgi $\mathrm{pH}$, providing a probable mechanism for GA swelling.

\section{ER pH is modestly increased in $U B E 3 A^{\mathrm{m}-/ \mathrm{p}^{+}}$neurons}

To determine whether Ube3a-dependent alteration of subcellular $\mathrm{pH}$ is exclusive to the GA, we also measured the $\mathrm{pH}$ of the mitochondria, cytoplasm, and ER in $U B E 3 A^{\mathrm{m}-/ \mathrm{p}^{+}}$and WT cortical neurons. The regulation of mitochondrial ion homeostasis is distinct from that of the secretory pathway (Casey et al., 2010), and the mitochondrial inner matrix is alkaline, with $\mathrm{pH} \sim 8$ (Llopis et al., 1998). Indeed, we observed no significant difference in pMito-YFP:pMito-CFP ratios between $U B E 3 A^{\mathrm{m}-/ \mathrm{p}+}$ and WT neurons (YFP/CFP, normalized to WT: WT $1.00 \pm 0.05, n=4$; $\left.U B E 3 A^{\mathrm{m}-/ \mathrm{p}+} 1.02 \pm 0.03, n=6 ; p=0.69\right)$, indicating that mitochondrial $\mathrm{pH}$ is unchanged in $U B E 3 A^{\mathrm{m}-/ \mathrm{p}+}$ neurons. We 
A

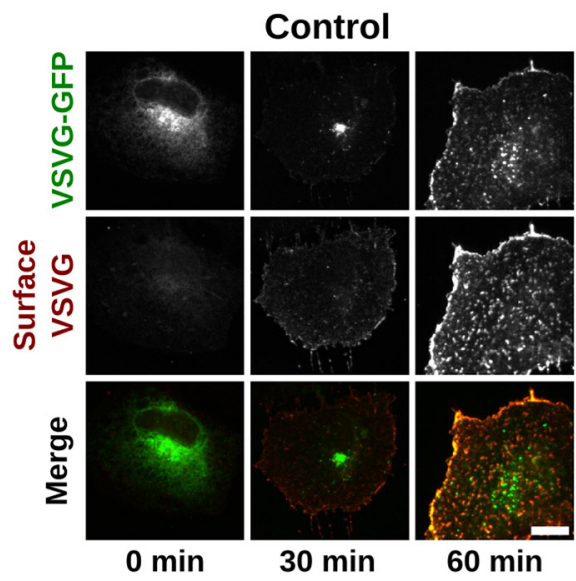

B

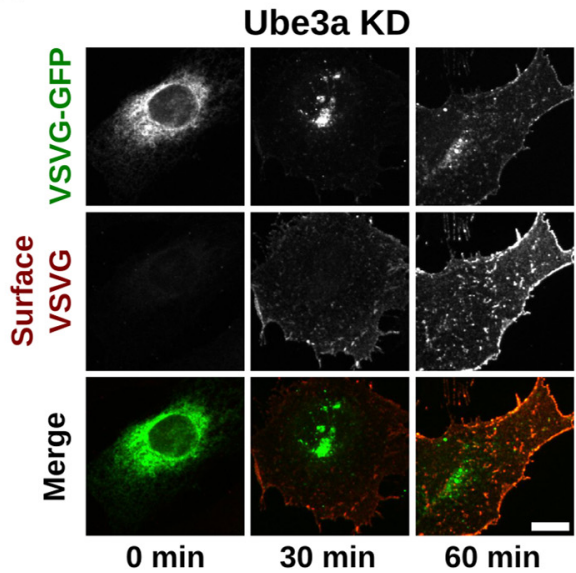

C

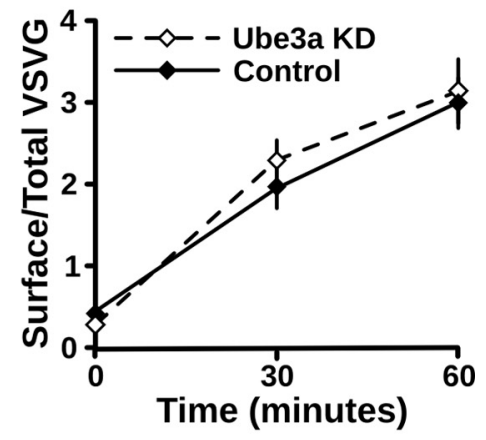

E
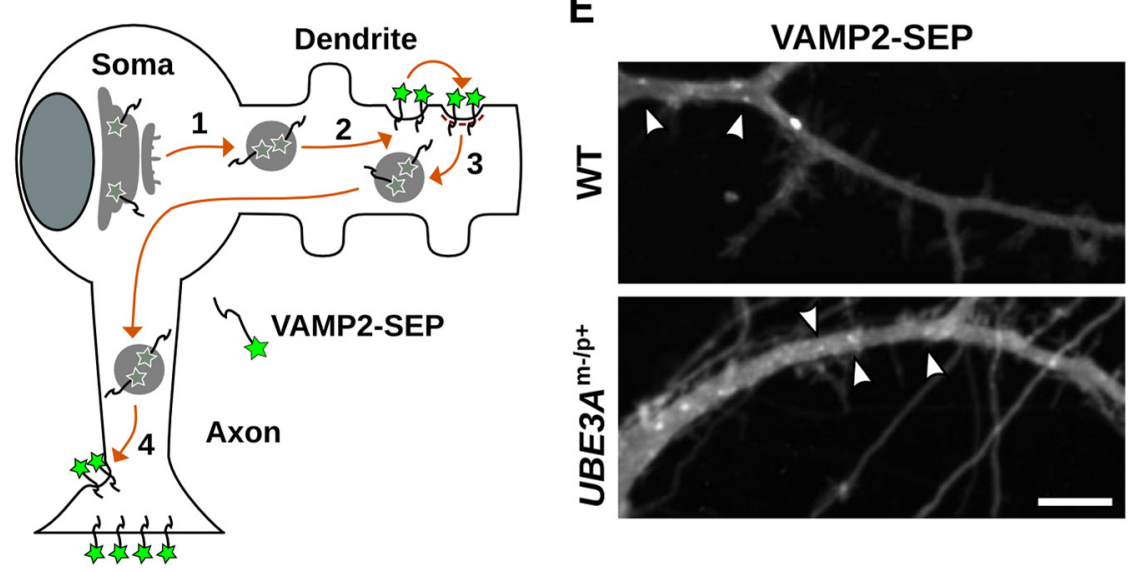

H

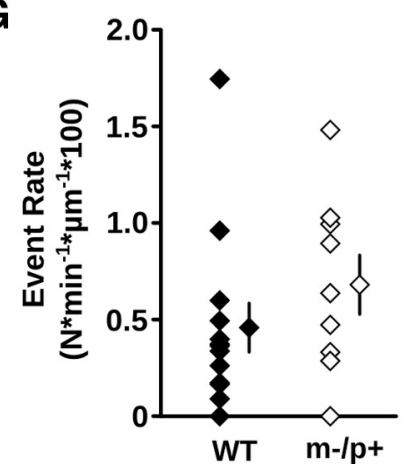

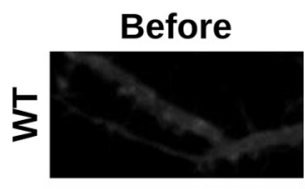

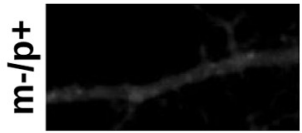

F
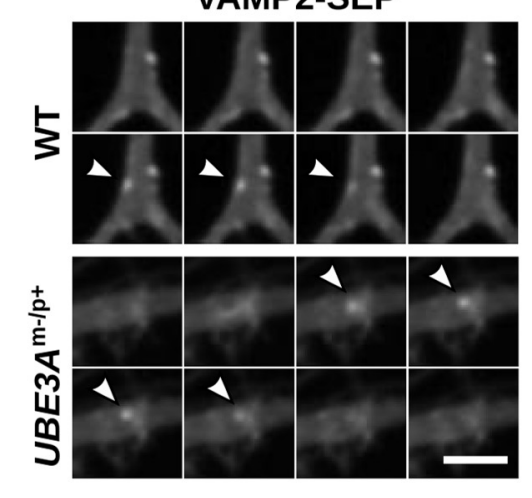

VAMP2-SEP 
A
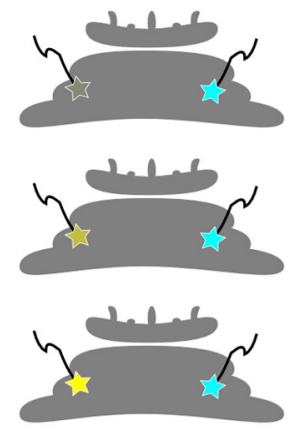

Golgi apparatus

pH 5.0

pH 7.0

$\eta_{\text {p }}$ polgi-YFP $\eta_{\text {p }}$ polgi-CFP

B

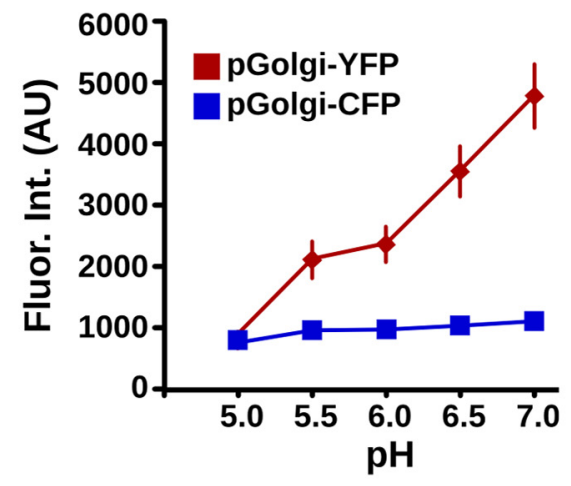

C

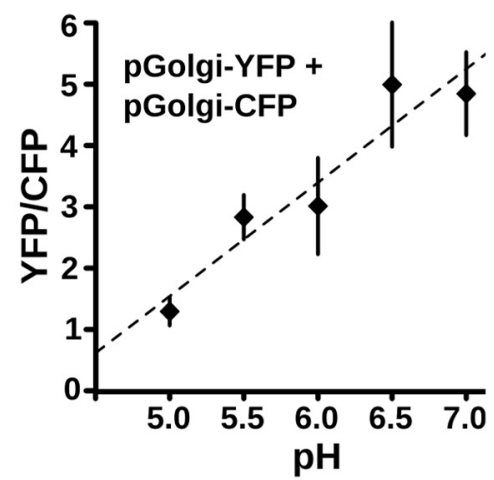

F

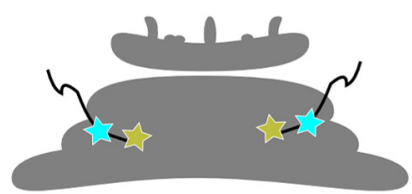

$\eta_{i=2}$ pGolgi-CFP-YFP

I

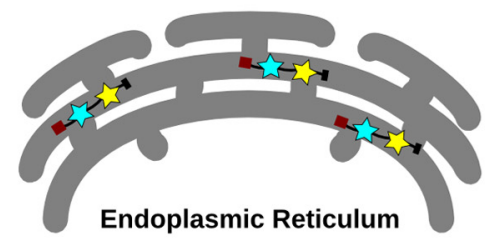

-
D

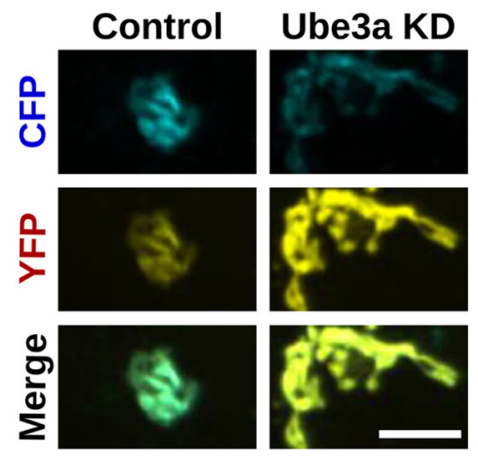

G

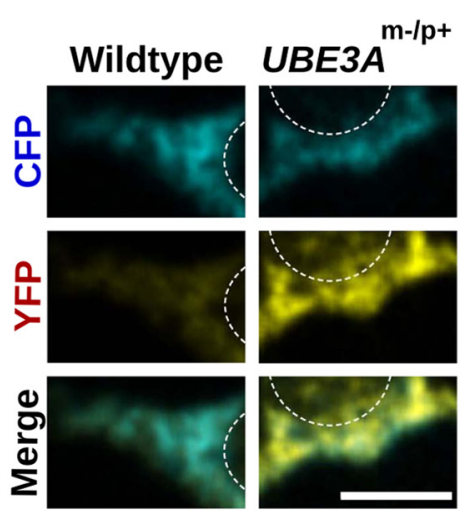

J

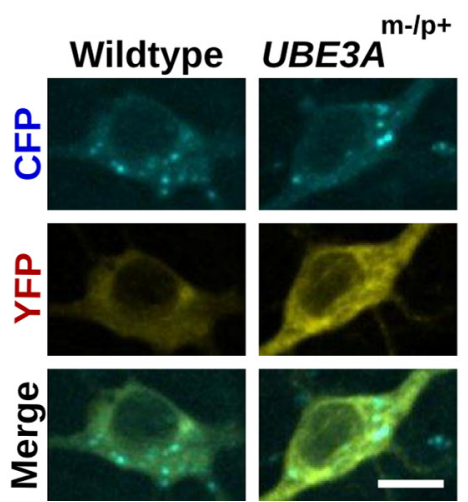

E

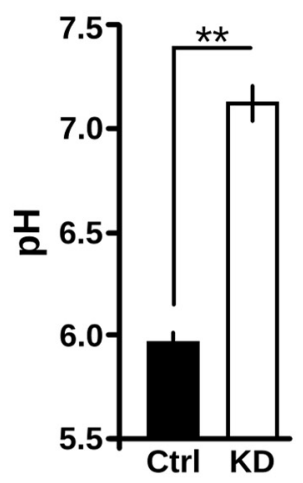

H

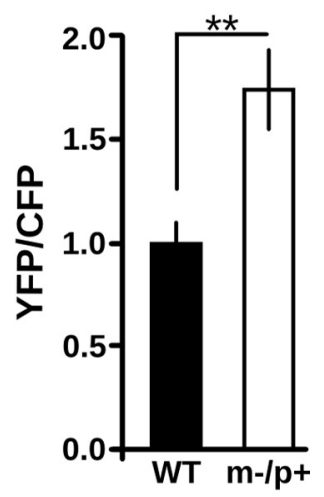

K

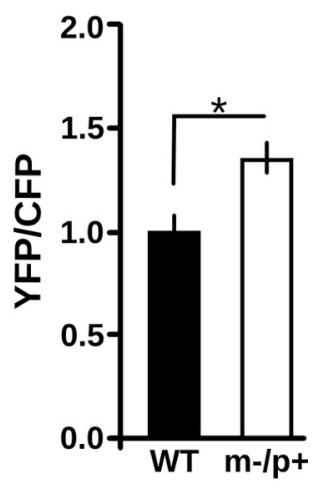

Figure 5. Golgi pH is elevated in Ube3a KD cells and in UBE3A ${ }^{\mathrm{m}-/ \mathrm{p}+}$ neurons. $\boldsymbol{A}-\boldsymbol{E}$, Golgi pH is elevated in Ube3a KD cells. $A$, Schematic illustrating the method used to measure Golgi pH. YFP and CFP fluorophores are directed to the lumen of the GA using the Golgi targeting domain of $\beta$-1,4-galactosyltransferase. YFP fluorescence increases as pH increases, whereas (Figure legend continues.) 
Sekine, 1981; Levy et al., 1990; Yu and Inesi, 1993; Hirota et al., 2006; Edwards and Kahl, 2010; Kuum et al., 2012) through mechanisms that may be partially shared with Golgi ion homeostasis. Interestingly, ER $\mathrm{pH}$ was moderately elevated in $U B E 3 A^{\mathrm{m}-/ \mathrm{p}+}$ neurons over WT neurons as indicated by an increase in the YFP:CFP intensity ratio of pER-CFP-YFP (YFP/CFP, normalized to WT: WT $1.00 \pm 0.08, n=10 ; U B E 3 A^{\mathrm{m}-/ \mathrm{p}^{+}} 1.35 \pm 0.08, n=$ $8 ; p<0.01$; Fig. $5 I-K)$. Thus, the GA acidification defect in Ube3a-deficient cells is likely the result of a mechanism partially shared with other compartments of the early secretory pathway.

\section{Reduction of Ube3a leads to deficits in surface sialylation}

Elevation of Golgi pH leads to cisternal swelling (Ledger et al., 1980; Boss et al., 1984; Thorens and Vassalli, 1986; Kellokumpu et al., 2002; Lázaro-Diéguez et al., 2006) and altered protein glycosylation (Niemann et al., 1982; Alonso-Caplen and Compans, 1983; Ledger and Tanzer, 1984; Axelsson et al., 2001; Kellokumpu et al., 2002; Maeda et al., 2008; Rivinoja et al., 2009). Regarding the latter, the enzymatic activity, trans-Golgi localization, and heteromeric complex formation of sialyltransferases are highly pH-sensitive (Axelsson et al., 2001, Rivinoja et al., 2009; Hassinen et al., 2011). Indeed, the elevation of Golgi $\mathrm{pH}$ by just $0.2 \mathrm{pH}$ units is sufficient to disrupt the addition of sialic acid to glycan structures in a linkage-specific manner (Rivinoja et al., 2009). Sialylation modulates interactions among proteins and lipids, thereby regulating cellular adhesion and cell signaling (Kleene and Schachner, 2004; Varki, 2007, 2008), including regulation of nervous system development and function (Castillo et al., 1997; Tyrrell et al., 2001; Kleene and Schachner, 2004; Isaev et al., 2007; Rutishauser, 2008; Yu et al., 2009; Repnikova et al., 2010). We thus reasoned that under-acidification of the GA in the absence of Ube3a might impair sialylation.

To determine whether Ube3a regulates sialylation, we took advantage of the SNA lectin, which binds selectively to terminal sialic acid residues added by an $\alpha-2,6$ linkage with galactose or $\mathrm{N}$-acetylgalactosamine on proteins and lipids (Fig. 6A) (Shibuya et al., 1987). Surface labeling using fluorescein-conjugated SNA revealed a marked reduction in surface sialylconjugates on Ube3a KD cells compared with control cells (Ube3a KD $41.3 \pm 6.0 \%$ of control, $n=8$; $p<0.01$; Fig. $6 B, C)$. Pretreatment with neuraminidase to remove terminal sialic acid residues from glycans

\footnotetext{
$\leftarrow$

(Figure legend continued.) (FP fluorescence is pH stable. B, C, Calibration of pGolgi-YFP: pGolgi-CFP ratios to absolute $\mathrm{pH}$ (see Materials and Methods). $\boldsymbol{B}$, Quantification of pGolgi-YFP and $\mathrm{pGolgi-CFP} \mathrm{fluorescence} \mathrm{(arbitrary} \mathrm{units)} \mathrm{at} \mathrm{various} \mathrm{defined} \mathrm{pH}$ values documenting their distinct $\mathrm{pH}$ sensitivities. C, Calibration curve (pGolgi-YFP:pGolgi-CFP fluorescence) used to calculate $\mathrm{pH}$ values. $\mathrm{pH}=0.53 \times$ YFP:CFP $+4.14, R^{2}=0.9$. D, pGolgi-YFP and pGolgi-CFP fluorescence in control and Ube3a KD cells. There is elevated pGolgi-YFP intensity in Ube3a KD cells compared with control cells. Scale bar, $10 \mu \mathrm{m}$. E, Quantification of Golgi pH in control (Ctrl) and Ube3a KD cells. ${ }^{* *} p<0.001$. $\boldsymbol{F}-\boldsymbol{H}$, Golgi pH is elevated in UBE $3 A^{\mathrm{m}-/ \mathrm{p}+}$ neurons. $\boldsymbol{F}$, Schematic of the probe used to measure Golgi pH in cultured cortical neurons. A Golgi pH probe with tandem (FP and YFP fluorophores (pGolgi-CFP-YFP) was expressed in cortical neurons cultured from WT and UBE3A ${ }^{\mathrm{m}-/ \mathrm{p}+}$ mice. G, pGolgi-CFP-YFP fluorescence in WT and $U B E 3 A^{m-/ p+}$ neurons. White circles outline the nuclear region for orientation. There is elevated YFP intensity in the UBE3 $A^{\mathrm{m}-/ \mathrm{p}+}$ neuron compared with the WT neuron. Scale bar, 10 $\mu \mathrm{m} . \boldsymbol{H}$, Average YFP:CFP fluorescence ratios of pGolgi-CFP-YFP in UBE $3 A^{\mathrm{m}-/ \mathrm{p}+}$ neurons normalized to values in WT. ${ }^{* *} p=0.001$. $I-K$, ER pH is modestly elevated in UBE3A ${ }^{\mathrm{m}-/ \mathrm{p}+}$ neurons. $I$, Schematic of the probe used to measure intralumenal ER pH. pER-CFP-YFP is a soluble protein targeted to the ER lumen by its $\mathrm{N}$-terminal calreticulin signal sequence and C-terminal KDEL retrieval sequence.J, pER-CFP-YFP fluorescence in WT and UBE3A ${ }^{\mathrm{m}-/ \mathrm{p}+}$ neurons. There is moderately elevated YFP intensity in the UBE3A ${ }^{\mathrm{m}-/ \mathrm{p}+}$ neuron compared with the WT neuron. Scale bar, $10 \mu \mathrm{m}$. $\boldsymbol{K}$, Average YFP:CFP fluorescence ratios of pER-CFP-YFP in UBE $3 A^{\mathrm{m}-/ \mathrm{p}+}$ neurons after normalization to values in WT. ${ }^{*} p<0.01$.
}

abolished surface SNA labeling in control cells (Fig. 6B), indicating the selectivity of SNA binding. In addition, we probed total cellular lysates from Ube3a KD and control cells with HRPconjugated SNA and observed a sharp reduction in sialylconjugates in Ube 3 a KD cells ( $45.2 \pm 4.9 \%$ of control, $n=7 ; p<0.001$; Fig. $6 D, E)$. Similar results were obtained with SNA-fluorescein and SNA-HRP in a separate Ube3a KD clone tested (SNAfluorescein signal normalized to control: KD2 $20.0 \pm 2.7 \%, n=$ $4 ; p<0.001$; SNA-HRP normalized to control: KD2 $39.6 \pm 5.4 \%$, $n=7 ; p<0.001)$.

As SNA detects only $\alpha-2,6$ linked sialylconjugates, we used an alternative method to isolate all surface proteins incorporating sialic acid residues. For this, we incubated cells with the synthetic sialic acid precusor $\mathrm{N}$-azidoacetylmannosamine (ManNAz), which can be covalently tagged with a FLAG-phosphine conjugate (Saxon and Bertozzi, 2000; Vocadlo et al., 2003). FLAGtagged species can then be isolated by immunoprecipitation with an anti-FLAG antibody under denaturing conditions (Fig. 6F; see Materials and Methods). Consistent with SNA lectin labeling, Ube3a KD cells had a significant reduction in immunopurified sialylconjugates (Ube3a KD $44.4 \pm 10.6 \%$ of control, $n=3$; $p<$ 0.05 ; Fig. $6 G, H)$. The metabolic labeling of sialyl conjugates was selective as the absence of ManNAz precursor or pretreatment of labeled cells with neuraminidase reduced the detection of FLAGpositive species to background levels (Fig. $6 G, H$ ). Together, these data indicate that cells lacking Ube3a have a marked reduction in surface sialylation, consistent with an under-acidified GA. Thus, altered Golgi ion homeostasis and defective glycosylation define a general defect in cells that lack the AS ubiquitin ligase Ube3a.

\section{Protein sialylation is reduced in $U B E 3 A^{-/-}$cortex}

Glycosylation notoriously differs between in vitro cell culture and in vivo tissue (Berger, 2002; Lowe and Marth, 2003; Ohtsubo and Marth, 2006; Varki et al., 2009), and the same mutations in glycosyltransferases tolerated in vitro are lethal in vivo (Ioffe and Stanley, 1994; Metzler et al., 1994; Lowe and Marth, 2003). Moreover, the overlapping substrate specificity of glycosyltransferases (Kono et al., 1997) introduces opportunities for developmental compensation that can lead to unexpectedly altered, rather than absent, glycan structures (Kotani et al., 2001). In addition, different cell types express different complements of enzymes for glycosylation (Varki, 2006; Takashima, 2008), and glycosyltransferases differ in their sensitivity to $\mathrm{pH}$ (Chen et al., 2000; Axelsson et al., 2001; Rivinoja et al., 2009; Hassinen et al., 2011). Therefore, we wished to determine whether sialylation is reduced in Ube3a-deficient brain and thus relevant to AS pathogenesis. We measured the abundance of SNA-reactive sialylconjugates in cortical lysates prepared from $U B E 3 A^{-1-}$ and WT mice and found a significant decrease in total protein $\alpha$-2,6-sialylation in $U B E 3 A^{-1-}$ cortex relative to WT cortex $\left(U B E 3 A^{-1-} 73.3 \pm\right.$ $5.5 \%$ of WT, $n=8 ; p<0.002$; Fig. 7 ). These results suggest there is a generalized deficit in sialylation in the Ube3a-deficent brain.

\section{Discussion}

Although understanding of synaptic and circuit defects in AS mouse models is now emerging, neither the cellular function of Ube3a nor the pathogenesis of AS is well understood. In this study, we uncovered an unanticipated phenotype of distended Golgi cisternae in $U B E 3 A^{\mathrm{m}-/ \mathrm{p}+}$ mouse cortex. The disrupted GA morphology is not the result of a generalized defect in secretory trafficking but rather associated with marked under-acidification of the Golgi lumen. Consistent with impaired Golgi acidification, Ube3a-deficient cells in vitro and in vivo exhibit significant 
A

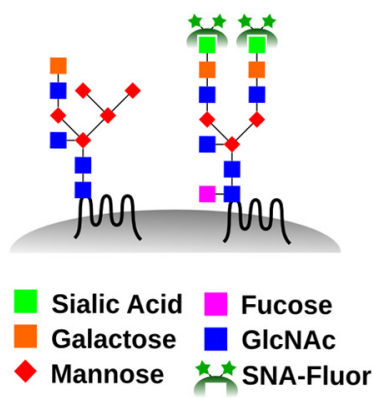

B

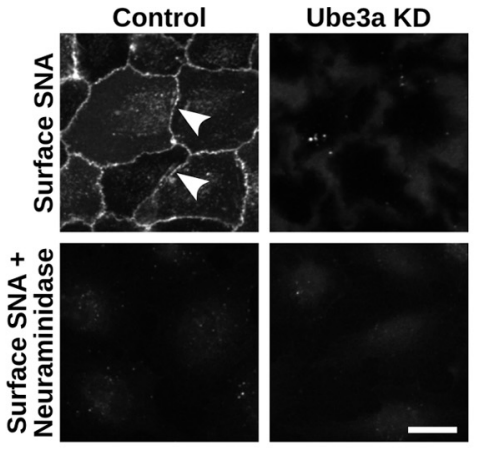

C

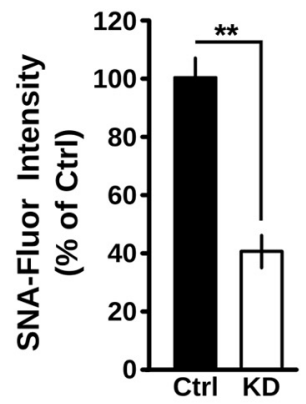

$\mathbf{F}$

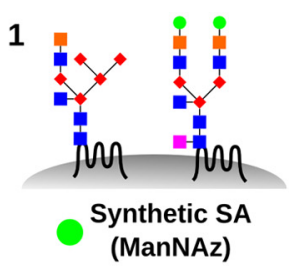

G

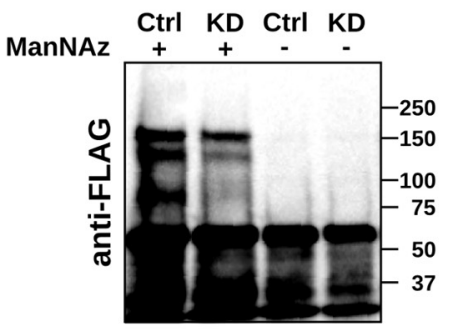

D
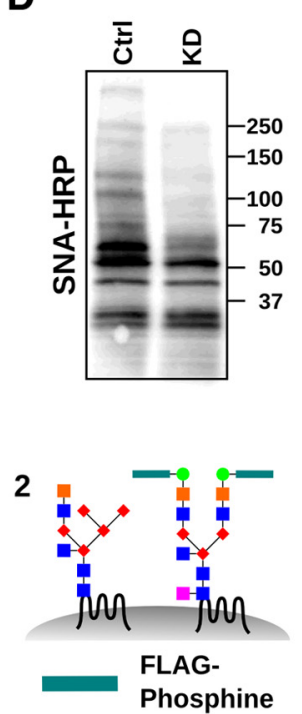

E

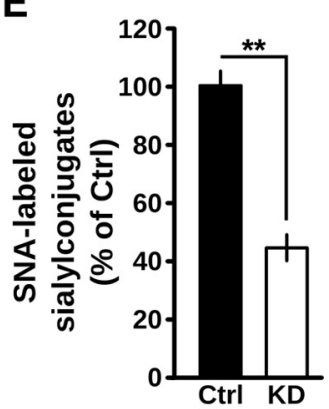

3

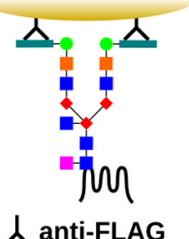

IP bead
H

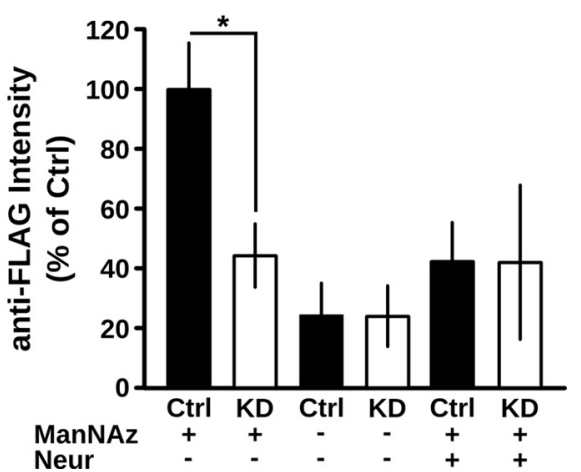

Figure 6. Loss of surface protein sialylation in cells lacking Ube3a. $\boldsymbol{A}-\boldsymbol{E}$, Loss of $\alpha$-2,6-sialic acid conjugates in Ube3a KD cells. $\boldsymbol{A}$, Schematic illustrating labeling of $\alpha$-2,6 linked sialic acid conjugates with SNA-fluorescein. GlcNAc, $N$-acetylglucosamine; Fluor, fluorescein . $\boldsymbol{B}$, Surface labeling of $\alpha$-2,6-sialic acid conjugates in control cells (cell membranes indicated with white arrowheads) and Ube3a KD cells using SNA-fluorescein. Pretreatment with neuraminidase abolished SNA labeling. Scale bar, $10 \mu \mathrm{m}$. C, Quantification of surface bound SNA-fluorescein on scrambled shRNA control (Ctrl) and Ube3a KD cells. ${ }^{* *} p<0.001 . D$, Total cellular lysates from control and Ube3a KD cells after SDS-PAGE and blotting with SNA-HRP. Molecular mass markers are shown. $\boldsymbol{E}$, Corresponding average integrated SNA-HRP signal demonstrating reduced sialylation in Ube3a KD cells. ${ }^{* *} p<0.001$. $\boldsymbol{F}-\boldsymbol{H}$, Reduction in total protein sialylation in Ube3a KD cells revealed by metabolic labeling. $\boldsymbol{F}$, Schematic illustrating metabolic labeling and isolation of sialylated proteins using covalent FLAG-phosphine chemistry (see Materials and Methods). ManNAz, a synthetic azide derivative precursor to sialic acid(SA), is incorporated into endogenous glycans $(\boldsymbol{F 1})$, allowing reaction and covalent tagging with FLAG-phosphine $(\boldsymbol{F 2})$, and immunoprecipitation with an anti-FLAG antibody $(\boldsymbol{F 3})$. G, FLAG immunoreactivity after SDS-PAGE and immunoblotting of immunoprecipitates from control (Ctrl) and Ube3a KD cells with $(+)$ or without (-) exposure to ManNAz. Molecular mass markers are shown. There are reduced levels of high molecular mass sialylconjugates in Ube3a KD cells and an absence of corresponding molecular species without prior metabolic labeling. The dark band at $\sim 55 \mathrm{kDa}$ is the lgG band from the immunoprecipitation. Species $<50 \mathrm{kDa}$ are nonspecific as they are present in the absence of ManNAz. $\boldsymbol{H}$, Average FLAG immunoreactivity $(>60 \mathrm{kDa}$ ) in immunoblots, such as shown in $\mathbf{G}$, and from samples exposed to ManNAz and treated with neuraminidase before FLAG-phosphine, defining background levels. There is reduction of protein sialylation in Ube3a KD cells. $p>0.3$ for Ube $3 a$ KD versus negative controls (ANOVA). ${ }^{*} p<0.05$ for Ube3a KD versus control.

reductions in protein sialylation, a posttranslational modification highly dependent on Golgi $\mathrm{pH}$. The discovery of a Golgi phenotype in $U B E 3 A^{\mathrm{m}-/ \mathrm{p}+}$ mice reveals a new Ube3a-regulated pathway that may contribute to AS pathogenesis.

In both Ube3a-deficient cortex and Ube3a KD cells, we observed severely distended Golgi cisternae without obvious disruption of other endomembrane structures. Distended Golgi have been observed in mice lacking the ATPbinding cassette transporter 1 (ABC1) or the secretory pathway $\mathrm{Ca}^{2+}$-ATPase 1 (SPCA1), models for Tangier and Hailey-Hailey diseases, respectively. Neither of these precisely phenocopies the $U B E 3 A^{\mathrm{m}-/ \mathrm{p}^{+}}$mice. Golgi abnormalities in $A B C 1^{-1-}$ mice are limited to the transGolgi network and accompanied by severely disrupted mitochondria (Orsó et al., 2000). Similarly, the swollen Golgi cisternae in SPCA1 $1^{-1-}$ tissues are accompanied by rough ER dilation and embryonic lethality (Okunade et al., 2007). Instead, the histological and physiological phenotypes we describe here closely resemble in vitro phenotypes induced by disruption of Golgi ion homeostasis, such as treatment of cells with drugs that neutralize Golgi pH (Thorens and Vassalli, 1986) or dysregulation of Golgi ion channels/exchangers (Maeda et al., 2008).

Intriguingly, several neurodevelopmental disorders may result from recently discovered mutations in genes controlling organellar ion homeostasis. In particular, an AS-mimicking phenotype was recently reported in Christianson syndrome patients with loss-of-function mutations in $\mathrm{Na}^{+} / \mathrm{H}^{+}$exchanger 6 (NHE6) (Gilfillan et al., 2008; Schroer et al., 2010), a regulator of organellar pH (Brett et al., 2002; Ohgaki et al., 2010). Similarly, NHE9 mutations were discovered in autistic patients (Morrow et al., 2008), and mutations in ATP6VOA2, encoding a $\mathrm{H}^{+}$vATPase subunit, result in cutis laxa with a high incidence of developmental delay and microcephaly (Hucthagowder et al., 2009). Moreover, SPCA2, a Golgilocalized calcium pump (Xiang et al., 2005), has been linked to specific language impairment (Newbury et al., 2009). The existence of multiple genetic associations with organellar ion homeostasis suggests a common set of cellular pathways whose disruption is sufficient to cause severe deficits in brain development. It will be important for future studies to define the relationship between Ube3a and the various molecular mechanisms regulating endomembrane $\mathrm{pH}$ and ion homeostasis. 
Despite a moderately increased ER $\mathrm{pH}$ in $U B E 3 A^{\mathrm{m}-/ \mathrm{p}+}$ neurons, we did not observe alterations in ER morphology in the Ube3a-deficient brain. The neutral $\mathrm{pH}$ of the ER is maintained by a combination of chloride channels/exchangers, potassium channels, and $\mathrm{H} \mathrm{H}^{+}$leak current, presumably via $\mathrm{K}^{+} / \mathrm{H}^{+}$exchange (Hirota et al., 2006; Edwards and Kahl, 2010; Kuum et al., 2012). Differences between ER and Golgi counterion permeability may account for lack of ER swelling in the Ube3a-deficient cortex. For example, whereas both the ER-localized SERCA and the Golgi-localized SPCA1 pump $\mathrm{Ca}^{2+}$ in and $\mathrm{H}^{+}$out, SERCA ${ }^{-1-}$ mice have a collapsed ER structure (Swift et al., 2012) and SPCA1 ${ }^{-1-}$ mice have swollen Golgi (Okunade et al., 2007). Alternatively, the modest increase in lumenal ER $\mathrm{pH}$ may be insufficient to induce a noticeable osmolarity change relative to the cytoplasm.

Although we have identified Golgi under-acidification as the likely cause of the distended Golgi phenotype, the mechanism by which Ube3a regulates Golgi $\mathrm{pH}$ remains undetermined. Perhaps the simplest explanation would be the existence of a Ube3a substrate that either directly or indirectly regulates Golgi $\mathrm{pH}$. The acidic $\mathrm{pH}$ of the GA is achieved by balancing active acidification by vacuolar $\mathrm{H}^{+}$-ATPases with chloride influx, cation exchange, and $\mathrm{H}^{+}$leak current, although the precise molecular identities and relative contributions of these are poorly understood (Casey et al., 2010). Given the overlapping phenotypes of AS and NHE6 mutations, an especially attractive mechanism would involve the organellar NHEs. These ubiquitously expressed $\left(\mathrm{Na}^{+}, \mathrm{K}^{+}\right) / \mathrm{H}^{+}$ exchangers concentrate in different subcellular compartments (NHE6, NHE9: endosomes; NHE7, NHE8: Golgi), and may contribute significantly to the $\mathrm{H}^{+}$leak current in the secretory pathway (Casey et al., 2010; Ohgaki et al., 2011). Notably, overexpression of NHE6 (Ohgaki et al., 2010), NHE8 (Nakamura et al., 2005), or NHE9 (Nakamura et al., 2005) leads to alkalinization of corresponding intracellular compartments. Therefore, mechanisms leading to an overabundance of one or more organellar ion exchangers in the GA, perhaps by ubiquitin-dependent regulation of NHE trafficking (Roxrud et al., 2009), would be compatible with our findings. Alternatively, the trafficking of plasma-membrane localized NHEs (e.g., NHE1) could be disrupted, resulting in their GA accumulation.

The postnatal onset of AS and grossly normal histology of AS patients and $U B E 3 A^{\mathrm{m}-/ \mathrm{p}+}$ mice suggest that Ube $3 \mathrm{a}$ is required for synaptic refinement, maintenance, and/or function. Golgi alkalinization impairs sialylation of diverse proteins and lipids (Thorens and Vassalli, 1986; Axelsson et al., 2001, Maeda et al., 2008; Rivinoja et al., 2009; Hirata et al., 2010), and we demonstrated here that loss of Ube3a reduces protein sialylation in both Ube3a KD cells and Ube3a-deficient mouse brain. In the brain, sialylation of proteins and lipids occurs in a developmentally regulated manner and regulates synapse formation, neurite outgrowth, neuron-glia interactions, ion channel properties, and neuronal excitability (Castillo et al., 1997; Tyrrell et al., 2001; Kleene and Schachner, 2004; Isaev et al., 2007; Rutishauser, 2008; Yu et al., 2009; Repnikova et al., 2010; Hu et al., 2011; Schwetz et al., 2011). Interestingly, alteration of lipid sialylation could conceivably explain the developmental delay in myelination in AS
B

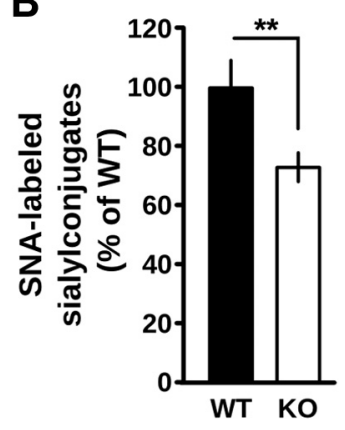

C

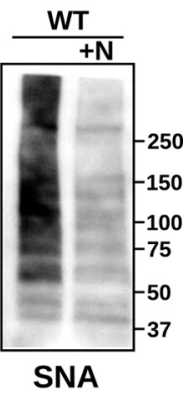

patients (Harting et al., 2009; Castro-Gago et al., 2010; Peters et al., 2011), a surprising phenotype given the absence of UBE3A imprinting in glial cells (Yamasaki et al., 2003). Myelination depends on interactions between membrane proteins and sialylated lipids (Schnaar and Lopez, 2009), and disrupting these interactions induces a developmental delay in myelination (Li et al., 1994; Montag et al., 1994; Sheikh et al., 1999). Reducing sialylation on several sodium and potassium ion channels significantly alters their conductance-voltage relationships and inactivation recovery rates (Bennett, 2002; Stocker and Bennett, 2006; Isaev et al., 2007; Schwetz et al., 2011). It will be interesting for future studies to determine whether reduced ion channel sialylation contributes to the stimulus-dependent long-term potentiation deficit, altered EEG patterns, or epilepsy in AS patients and AS model mice (Mabb et al., 2011). GA dysfunction can also disrupt dendritic branching and polarization (Hanus and Ehlers, 2008). Notably, Miao et al. (2013) recently reported altered dendritic branching, accompanied by altered GA polarization, in Ube3adeficient neurons.

At the GA, the most prominent role for ubiquitination is sorting, rather than degradation, of protein substrates. In particular, ubiquitination regulates GGA-mediated sorting of cargo at the trans-Golgi network (Bonifacino, 2004) and postmitotic Golgi reassembly via the AAA ATPase p97 (Meyer, 2005). To date, Ube3a has only been shown to form K48-linked polyubiquitin chains on protein substrates (Kim et al., 2007), suggesting that a sorting role for Ube3a is less likely. However, proteasome inhibition can induce reversible Golgi fragmentation (Harada et al., 2003), suggesting that proteolytic functions of the ubiquitin pathway are also critical for Golgi integrity. Interestingly, the putative Ube3a substrate HHR23 (Kumar et al., 1999) was isolated with p97 (Besche et al., 2009), although the significance of this interaction is unknown. Identification of Ube3a as a regulator of Golgi ion homeostasis provides a new function for Ube3a and may reveal a new role for protein degradation as a regulator of the GA.

The recent description of proteins that regulate Golgi ion homeostasis provide targets for precise genetic manipulation of organellar $\mathrm{pH}$ in cellular and in vivo systems. Although several diseases linked to organellar ion homeostasis have recently been described (Gilfillan et al., 2008; Morrow et al., 2008; Hucthagowder et al., 2009; Newbury et al., 2009), the role of organellar $\mathrm{pH}$ in neuronal development and synaptic 
plasticity remains poorly understood. Examination of the effects of genetic or drug manipulation of these factors on a Ube3a-deficient background would provide insight into which AS phenotypes can be attributed to disruption of Golgi ion homeostasis. A set of small-molecule inhibitors have been developed for the cell-surface targeted NHE1 and evaluated for cardioprotective effects in clinical trials (Masereel et al., 2003; Slepkov et al., 2007), suggesting that specific drugs could be discovered for other NHEs.

The etiology of AS is relatively simple, as a single mutation in a single gene is sufficient to cause the disease (Cooper et al., 2004). However, it has become increasingly clear that AS pathogenesis is complex, with Ube3a regulating diverse pathways. In this study, we have described a novel phenotype of severely distended Golgi cisternae in the AS model mouse, accompanied by Golgi underacidification and a reduction in protein sialylation in cells lacking Ube3a. We propose that Ube3a has a role in the maintenance of Golgi ion homeostasis and that Golgi under-acidification could underlie deficits in neuronal function and plasticity observed in $U B E 3 A^{\mathrm{m}-/ \mathrm{p}+}$ mice and AS patients.

\section{References}

Abrahams BS, Geschwind DH (2008) Advances in autism genetics: on the threshold of a new neurobiology. Nat Rev Genet 9:341-355. CrossRef Medline

Albrecht U, Sutcliffe JS, Cattanach BM, Beechey CV, Armstrong D, Eichele G, Beaudet AL (1997) Imprinted expression of the murine Angelman syndrome gene, Ube3a, in hippocampal and Purkinje neurons. Nat Genet 17:75-78. CrossRef Medline

Alonso-Caplen FV, Compans RW (1983) Modulation of glycosylation and transport of viral membrane glycoproteins by a sodium ionophore. J Cell Biol 97:659-668. CrossRef Medline

Axelsson MA, Karlsson NG, Steel DM, Ouwendijk J, Nilsson T, Hansson GC (2001) Neutralization of $\mathrm{pH}$ in the Golgi apparatus causes redistribution of glycosyltransferases and changes in the O-glycosylation of mucins. Glycobiology 11:633-644. CrossRef Medline

Bennett ES (2002) Isoform-specific effects of sialic acid on voltagedependent $\mathrm{Na}+$ channel gating: functional sialic acids are localized to the S5-S6 loop of domain I. J Physiol 538:675-690. CrossRef Medline

Berger EG (2002) Ectopic localizations of Golgi glycosyltransferases. Glycobiology 12:29R-36R. CrossRef Medline

Besche HC, Haas W, Gygi SP, Goldberg AL (2009) Isolation of mammalian $26 \mathrm{~S}$ proteasomes and p97/VCP complexes using the ubiquitin-like domain from HHR23B reveals novel proteasome-associated proteins. Biochemistry 48:2538-2549. CrossRef Medline

Bonifacino JS (2004) The GGA proteins: adaptors on the move. Nat Rev Mol Cell Biol 5:23-32. CrossRef Medline

Boss WF, Morré DJ, Mollenhauer HH (1984) Monensin-induced swelling of Golgi apparatus cisternae mediated by a proton gradient. Eur J Cell Biol 34:1-8. Medline

Brett CL, Wei Y, Donowitz M, Rao R (2002) Human $\mathrm{Na}(+) / \mathrm{H}(+)$ exchanger isoform 6 is found in recycling endosomes of cells, not in mitochondria. Am J Physiol Cell Physiol 282:C1031-C1041. CrossRef Medline

Bucan M, Abrahams BS, Wang K, Glessner JT, Herman EI, Sonnenblick LI, Alvarez Retuerto AI, Imielinski M, Hadley D, Bradfield JP, Kim C, Gidaya NB, Lindquist I, Hutman T, Sigman M, Kustanovich V, Lajonchere CM, Singleton A, Kim J, Wassink TH, et al. (2009) Genome-wide analyses of exonic copy number variants in a family-based study point to novel autism susceptibility genes. PLoS Genet 5:e1000536. CrossRef Medline

Burghardt RC, Droleskey R (2006) Transmission electron microscopy. Curr Protoc Microbiol Chapter 2:Unit 2B.1. CrossRef Medline

Cao H, Weller S, Orth JD, Chen J, Huang B, Chen JL, Stamnes M, McNiven MA (2005) Actin and Arfl-dependent recruitment of a cortactindynamin complex to the Golgi regulates post-Golgi transport. Nat Cell Biol 7:483-492. CrossRef Medline

Casey JR, Grinstein S, Orlowski J (2010) Sensors and regulators of intracellular pH. Nat Rev Mol Cell Biol 11:50-61. CrossRef Medline

Castillo C, Díaz ME, Balbi D, Thornhill WB, Recio-Pinto E (1997) Changes in sodium channel function during postnatal brain development reflect increases in the level of channel sialidation. Brain Res Dev Brain Res 104:119-130. CrossRef Medline

Castro-Gago M, Gómez-Lado C, Eirís-Puñal J, Rodríguez-Mugico VM (2010) Abnormal myelination in Angelman syndrome. Eur J Paediatr Neurol 14:292. CrossRef Medline

Chamberlain SJ, Lalande M (2010) Angelman syndrome, a genomic imprinting disorder of the brain. J Neurosci 30:9958-9963. CrossRef Medline

Chanat E, Huttner WB (1991) Milieu-induced, selective aggregation of regulated secretory proteins in the trans-Golgi network. J Cell Biol 115:15051519. CrossRef Medline

Chen C, Ma J, Lazic A, Backovic M, Colley KJ (2000) Formation of insoluble oligomers correlates with ST6Gal I stable localization in the golgi. J Biol Chem 275:13819-13826. CrossRef Medline

Cooper EM, Hudson AW, Amos J, Wagstaff J, Howley PM (2004) Biochemical analysis of Angelman syndrome-associated mutations in the E3 ubiquitin ligase E6-associated protein. J Biol Chem 279:41208-41217. CrossRef Medline

Cui-Wang T, Hanus C, Cui T, Helton T, Bourne J, Watson D, Harris KM, Ehlers MD (2012) Local zones of endoplasmic reticulum complexity confine cargo in neuronal dendrites. Cell 148:309-321. CrossRef Medline

Dindot SV, Antalffy BA, Bhattacharjee MB, Beaudet AL (2008) The Angelman syndrome ubiquitin ligase localizes to the synapse and nucleus, and maternal deficiency results in abnormal dendritic spine morphology. Hum Mol Genet 17:111-118. CrossRef Medline

Edwards JC, Kahl CR (2010) Chloride channels of intracellular membranes. FEBS Lett 584:2102-2111. CrossRef Medline

Egea G, Francí C, Gambús G, Lesuffleur T, Zweibaum A, Real FX (1993) cis-Golgi resident proteins and O-glycans are abnormally compartmentalized in the RER of colon cancer cells. J Cell Sci 105:819-830. Medline

Farinas J, Verkman AS (1999) Receptor-mediated targeting of fluorescent probes in living cells. J Biol Chem 274:7603-7606. CrossRef Medline

Gilfillan GD, Selmer KK, Roxrud I, Smith R, Kyllerman M, Eiklid K, Kroken M, Mattingsdal M, Egeland T, Stenmark H, Sjøholm H, Server A, Samuelsson L, Christianson A, Tarpey P, Whibley A, Stratton MR, Futreal PA, Teague J, Edkins S, et al. (2008) SLC9A6 mutations cause X-linked mental retardation, microcephaly, epilepsy, and ataxia, a phenotype mimicking Angelman syndrome. Am J Hum Genet 82:1003-1010. CrossRef Medline

Glessner JT, Wang K, Cai G, Korvatska O, Kim CE, Wood S, Zhang H, Estes A, Brune CW, Bradfield JP, Imielinski M, Frackelton EC, Reichert J, Crawford EL, Munson J, Sleiman PM, Chiavacci R, Annaiah K, Thomas K, Hou C, et al. (2009) Autism genome-wide copy number variation reveals ubiquitin and neuronal genes. Nature 459:569-573. CrossRef Medline

Gonatas NK, Stieber A, Gonatas JO (2006) Fragmentation of the Golgi apparatus in neurodegenerative diseases and cell death. J Neurol Sci 246:21-30. CrossRef Medline

Greer PL, Hanayama R, Bloodgood BL, Mardinly AR, Lipton DM, Flavell SW, Kim TK, Griffith EC, Waldon Z, Maehr R, Ploegh HL, Chowdhury S, Worley PF, Steen J, Greenberg ME (2010) The Angelman syndrome protein Ube3A regulates synapse development by ubiquitinating arc. Cell 140:704-716. CrossRef Medline

Griffiths G, Fuller SD, Back R, Hollinshead M, Pfeiffer S, Simons K (1989) The dynamic nature of the Golgi complex. J Cell Biol 108:277-297. CrossRef Medline

Gustin RM, Bichell TJ, Bubser M, Daily J, Filonova I, Mrelashvili D, Deutch AY, Colbran RJ, Weeber EJ, Haas KF (2010) Tissue-specific variation of Ube3a protein expression in rodents and in a mouse model of Angelman syndrome. Neurobiol Dis 39:283-291. CrossRef Medline

Han J, Burgess K (2010) Fluorescent indicators for intracellular pH. Chem Rev 110:2709-2728. CrossRef Medline

Hanus C, Ehlers MD (2008) Secretory outposts for the local processing of membrane cargo in neuronal dendrites. Traffic 9:1437-1445. CrossRef Medline

Harada M, Kumemura H, Omary MB, Kawaguchi T, Maeyama N, Hanada S, Taniguchi E, Koga H, Suganuma T, Ueno T, Sata M (2003) Proteasome inhibition induces inclusion bodies associated with intermediate filaments and fragmentation of the Golgi apparatus. Exp Cell Res 288:60-69. CrossRef Medline

Harting I, Seitz A, Rating D, Sartor K, Zschocke J, Janssen B, Ebinger F, Wolf 
NI (2009) Abnormal myelination in Angelman syndrome. Eur J Paediatr Neurol 13:271-276. CrossRef Medline

Hassinen A, Pujol FM, Kokkonen N, Pieters C, Kihlström M, Korhonen K, Kellokumpu S (2011) Functional organization of Golgi N- and $\mathrm{O}$-glycosylation pathways involves $\mathrm{pH}$-dependent complex formation that is impaired in cancer cells. J Biol Chem 286:38329-38340. CrossRef Medline

Hirata Y, Shimokawa N, Oh-hashi K, Yu ZX, Kiuchi K (2010) Acidification of the Golgi apparatus is indispensable for maturation but not for cell surface delivery of Ret. J Neurochem 115:606-613. CrossRef Medline

Hirota S, Trimble N, Pertens E, Janssen LJ (2006) Intracellular Cl- fluxes play a novel role in $\mathrm{Ca}^{2+}$ handling in airway smooth muscle. Am J Physiol Lung Cell Mol Physiol 290:L1146-L1153. CrossRef Medline

Horton AC, Ehlers MD (2003) Dual modes of endoplasmic reticulum-toGolgi transport in dendrites revealed by live-cell imaging. J Neurosci 23:6188-6199. Medline

Horton AC, Rácz B, Monson EE, Lin AL, Weinberg RJ, Ehlers MD (2005) Polarized secretory trafficking directs cargo for asymmetric dendrite growth and morphogenesis. Neuron 48:757-771. CrossRef Medline

Hu J, Fei J, Reutter W, Fan H (2011) Involvement of sialic acid in the regulation of $\gamma$-aminobutyric acid uptake activity of $\gamma$-aminobutyric acid transporter 1. Glycobiology 21:329-339. CrossRef Medline

Huang C, Chang A (2011) pH-dependent cargo sorting from the Golgi. J Biol Chem 286:10058-10065. CrossRef Medline

Huang HS, Allen JA, Mabb AM, King IF, Miriyala J, Taylor-Blake B, Sciaky N, Dutton JW Jr, Lee HM, Chen X, Jin J, Bridges AS, Zylka MJ, Roth BL, Philpot BD (2012) Topoisomerase inhibitors unsilence the dormant allele of Ube3a in neurons. Nature 481:185-189. CrossRef Medline

Hucthagowder V, Morava E, Kornak U, Lefeber DJ, Fischer B, Dimopoulou A, Aldinger A, Choi J, Davis EC, Abuelo DN, Adamowicz M, Al-Aama J, Basel-Vanagaite L, Fernandez B, Greally MT, Gillessen-Kaesbach G, Kayserili H, Lemyre E, Tekin M, Türkmen S, et al. (2009) Loss-of-function mutations in ATP6V0A2 impair vesicular trafficking, tropoelastin secretion and cell survival. Hum Mol Genet 18:2149-2165. CrossRef Medline

Ioffe E, Stanley P (1994) Mice lacking N-acetylglucosaminyltransferase I activity die at mid-gestation, revealing an essential role for complex or hybrid N-linked carbohydrates. Proc Natl Acad Sci U S A 91:728-732. CrossRef Medline

Isaev D, Isaeva E, Shatskih T, Zhao Q, Smits NC, Shworak NW, Khazipov R, Holmes GL (2007) Role of extracellular sialic acid in regulation of neuronal and network excitability in the rat hippocampus. J Neurosci 27 : 11587-11594. CrossRef Medline

Jeong KW, Kim HZ, Kim S, Kim YS, Choe J (2007) Human papillomavirus type $16 \mathrm{E} 6$ protein interacts with cystic fibrosis transmembrane regulatorassociated ligand and promotes E6-associated protein-mediated ubiquitination and proteasomal degradation. Oncogene 26:487-499. CrossRef Medline

Jiang YH, Armstrong D, Albrecht U, Atkins CM, Noebels JL, Eichele G, Sweatt JD, Beaudet AL (1998) Mutation of the Angelman ubiquitin ligase in mice causes increased cytoplasmic p53 and deficits of contextual learning and long-term potentiation. Neuron 21:799-811. CrossRef Medline

Jung SY, Malovannaya A, Wei J, O’Malley BW, Qin J (2005) Proteomic analysis of steady-state nuclear hormone receptor coactivator complexes. Mol Endocrinol 19:2451-2465. CrossRef Medline

Kellokumpu S, Sormunen R, Kellokumpu I (2002) Abnormal glycosylation and altered Golgi structure in colorectal cancer: dependence on intraGolgi pH. FEBS Lett 516:217-224. CrossRef Medline

Kennedy MJ, Davison IG, Robinson CG, Ehlers MD (2010) Syntaxin-4 defines a domain for activity-dependent exocytosis in dendritic spines. Cell 141:524-535. CrossRef Medline

Kim HT, Kim KP, Lledias F, Kisselev AF, Scaglione KM, Skowyra D, Gygi SP, Goldberg AL (2007) Certain pairs of ubiquitin-conjugating enzymes (E2s) and ubiquitin-protein ligases (E3s) synthesize nondegradable forked ubiquitin chains containing all possible isopeptide linkages. J Biol Chem 282:17375-17386. CrossRef Medline

Kim JH, Lingwood CA, Williams DB, Furuya W, Manolson MF, Grinstein S (1996) Dynamic measurement of the $\mathrm{pH}$ of the Golgi complex in living cells using retrograde transport of the verotoxin receptor. J Cell Biol 134: 1387-1399. CrossRef Medline

Kleene R, Schachner M (2004) Glycans and neural cell interactions. Nat Rev Neurosci 5:195-208. CrossRef Medline

Kleijnen MF, Shih AH, Zhou P, Kumar S, Soccio RE, Kedersha NL, Gill G,
Howley PM (2000) The hPLIC proteins may provide a link between the ubiquitination machinery and the proteasome. Mol Cell 6:409-419. CrossRef Medline

Kono M, Ohyama Y, Lee YC, Hamamoto T, Kojima N, Tsuji S (1997) Mouse $\beta$-galactoside alpha 2,3-sialyltransferases: comparison of in vitro substrate specificities and tissue specific expression. Glycobiology 7:469479. CrossRef Medline

Kotani N, Asano M, Iwakura Y, Takasaki S (2001) Knockout of mouse beta 1,4-galactosyltransferase-1 gene results in a dramatic shift of outer chain moieties of N-glycans from type 2 to type 1 chains in hepatic membrane and plasma glycoproteins. Biochem J 357:827-834. CrossRef Medline

Kumar S, Talis AL, Howley PM (1999) Identification of HHR23A as a substrate for E6-associated protein-mediated ubiquitination. J Biol Chem 274:18785-18792. CrossRef Medline

Kuum M, Veksler V, Liiv J, Ventura-Clapier R, Kaasik A (2012) Endoplasmic reticulum potassium-hydrogen exchanger and small conductance calcium-activated potassium channel activities are essential for ER calcium uptake in neurons and cardiomyocytes. J Cell Sci 125:625-633. CrossRef Medline

Ladinsky MS, Wu CC, McIntosh S, McIntosh JR, Howell KE (2002) Structure of the Golgi and distribution of reporter molecules at 20 degrees $\mathrm{C}$ reveals the complexity of the exit compartments. Mol Biol Cell 13:2810-2825. CrossRef Medline

Lasiecka ZM, Winckler B (2011) Mechanisms of polarized membrane trafficking in neurons: focusing in on endosomes. Mol Cell Neurosci 48:278 287. CrossRef Medline

Lázaro-Diéguez F, Jiménez N, Barth H, Koster AJ, Renau-Piqueras J, Llopis JL, Burger KN, Egea G (2006) Actin filaments are involved in the maintenance of Golgi cisternae morphology and intra-Golgi pH. Cell Motil Cytoskeleton 63:778-791. CrossRef Medline

Ledger PW, Tanzer ML (1984) Monensin: a perturbant of cellular physiology. Trends Biochem Sci 9:313-314. CrossRef

Ledger PW, Uchida N, Tanzer ML (1980) Immunocytochemical localization of procollagen and fibronectin in human fibroblasts: effects of the monovalent ionophore, monensin. J Cell Biol 87:663-671. CrossRef Medline

Levy D, Seigneuret M, Bluzat A, Rigaud JL (1990) Evidence for proton countertransport by the sarcoplasmic reticulum Ca2(+)-ATPase during calcium transport in reconstituted proteoliposomes with low ionic permeability. J Biol Chem 265:19524-19534. Medline

Li C, Tropak MB, Gerlai R, Clapoff S, Abramow-Newerly W, Trapp B, Peterson A, Roder J (1994) Myelination in the absence of myelin-associated glycoprotein. Nature 369:747-750. CrossRef Medline

Lippincott-Schwartz J, Roberts TH, Hirschberg K (2000) Secretory protein trafficking and organelle dynamics in living cells. Annu Rev Cell Dev Biol 16:557-589. CrossRef Medline

Llopis J, McCaffery JM, Miyawaki A, Farquhar MG, Tsien RY (1998) Measurement of cytosolic, mitochondrial, and Golgi pH in single living cells with green fluorescent proteins. Proc Natl Acad Sci U S A 95:6803-6808. CrossRef Medline

Lowe JB, Marth JD (2003) A genetic approach to Mammalian glycan function. Annu Rev Biochem 72:643-691. CrossRef Medline

Mabb AM, Judson MC, Zylka MJ, Philpot BD (2011) Angelman syndrome: insights into genomic imprinting and neurodevelopmental phenotypes. Trends Neurosci 34:293-303. CrossRef Medline

Maeda Y, Ide T, Koike M, Uchiyama Y, Kinoshita T (2008) GPHR is a novel anion channel critical for acidification and functions of the Golgi apparatus. Nat Cell Biol 10:1135-1145. CrossRef Medline

Martínez-Noël G, Galligan JT, Sowa ME, Arndt V, Overton TM, Harper JW, Howley PM (2012) Identification and proteomic analysis of distinct UBE3A/E6AP protein complexes. Mol Cell Biol 32:3095-3106. CrossRef Medline

Masereel B, Pochet L, Laeckmann D (2003) An overview of inhibitors of $\mathrm{Na}(+) / \mathrm{H}(+)$ exchanger. Eur J Med Chem 38:547-554. CrossRef Medline

Metzler M, Gertz A, Sarkar M, Schachter H, Schrader JW, Marth JD (1994) Complex asparagine-linked oligosaccharides are required for morphogenic events during post-implantation development. EMBO J 13:20562065. Medline

Meyer HH (2005) Golgi reassembly after mitosis: the AAA family meets the ubiquitin family. Biochim Biophys Acta 1744:108-119. CrossRef Medline

Miao S, Chen R, Ye J, Tan GH, Li S, Zhang J, Jiang YH, Xiong ZQ (2013) The Angelman syndrome protein Ube3a is required for polarized dendrite 
morphogenesis in pyramidal neurons. J Neurosci 33:327-333. CrossRef Medline

Miesenböck G, De Angelis DA, Rothman JE (1998) Visualizing secretion and synaptic transmission with $\mathrm{pH}$-sensitive green fluorescent proteins. Nature 394:192-195. CrossRef Medline

Montag D, Giese KP, Bartsch U, Martini R, Lang Y, Blüthmann H, Karthigasan J, Kirschner DA, Wintergerst ES, Nave KA (1994) Mice deficient for the myelin-associated glycoprotein show subtle abnormalities in myelin. Neuron 13:229-246. CrossRef Medline

Morrow EM, Yoo SY, Flavell SW, Kim TK, Lin Y, Hill RS, Mukaddes NM, Balkhy S, Gascon G, Hashmi A, Al-Saad S, Ware J, Joseph RM, Greenblatt R, Gleason D, Ertelt JA, Apse KA, Bodell A, Partlow JN, Barry B, et al. (2008) Identifying autism loci and genes by tracing recent shared ancestry. Science 321:218-223. CrossRef Medline

Nakamura N, Tanaka S, Teko Y, Mitsui K, Kanazawa H (2005) Four $\mathrm{Na}^{+} / \mathrm{H}^{+}$exchanger isoforms are distributed to Golgi and post-Golgi compartments and are involved in organelle $\mathrm{pH}$ regulation. J Biol Chem 280:1561-1572. CrossRef Medline

Newbury DF, Winchester L, Addis L, Paracchini S, Buckingham LL, Clark A, Cohen W, Cowie H, Dworzynski K, Everitt A, Goodyer IM, Hennessy E, Kindley AD, Miller LL, Nasir J, O'Hare A, Shaw D, Simkin Z, Simonoff E, Slonims V, et al. (2009) CMIP and ATP2C2 modulate phonological short-term memory in language impairment. Am J Hum Genet 85:264272. CrossRef Medline

Niemann H, Boschek B, Evans D, Rosing M, Tamura T, Klenk HD (1982) Post-translational glycosylation of coronavirus glycoprotein E1: inhibition by monensin. EMBO J 1:1499-1504. Medline

Nurmi EL, Bradford Y, Chen Y, Hall J, Arnone B, Gardiner MB, Hutcheson HB, Gilbert JR, Pericak-Vance MA, Copeland-Yates SA, Michaelis RC, Wassink TH, Santangelo SL, Sheffield VC, Piven J, Folstein SE, Haines JL, Sutcliffe JS, et al. (2001) Linkage disequilibrium at the Angelman syndrome gene UBE3A in autism families. Genomics 77:105-113. CrossRef Medline

Oda H, Kumar S, Howley PM (1999) Regulation of the Src family tyrosine kinase Blk through E6AP-mediated ubiquitination. Proc Natl Acad Sci U S A 96:9557-9562. CrossRef Medline

Ohgaki R, Matsushita M, Kanazawa H, Ogihara S, Hoekstra D, van Ijzendoorn SC (2010) $\mathrm{The}^{\mathrm{Na}}{ }^{+} / \mathrm{H}^{+}$exchanger NHE6 in the endosomal recycling system is involved in the development of apical bile canalicular surface domains in HepG2 cells. Mol Biol Cell 21:1293-1304. CrossRef Medline

Ohgaki R, van IJzendoorn SC, Matsushita M, Hoekstra D, Kanazawa H (2011) Organellar $\mathrm{Na}^{+} / \mathrm{H}^{+}$exchangers: novel players in organelle $\mathrm{pH}$ regulation and their emerging functions. Biochemistry 50:443-450. CrossRef Medline

Ohtsubo K, Marth JD (2006) Glycosylation in cellular mechanisms of health and disease. Cell 126:855-867. CrossRef Medline

Okunade GW, Miller ML, Azhar M, Andringa A, Sanford LP, Doetschman T, Prasad V, Shull GE (2007) Loss of the Atp2c1 secretory pathway $\mathrm{Ca}(2+)$-ATPase (SPCA1) in mice causes Golgi stress, apoptosis, and midgestational death in homozygous embryos and squamous cell tumors in adult heterozygotes. J Biol Chem 282:26517-26527. CrossRef Medline

Orsó E, Broccardo C, Kaminski WE, Böttcher A, Liebisch G, Drobnik W, Götz A, Chambenoit O, Diederich W, Langmann T, Spruss T, Luciani MF, Rothe G, Lackner KJ, Chimini G, Schmitz G (2000) Transport of lipids from Golgi to plasma membrane is defective in tangier disease patients and Abcl-deficient mice. Nat Genet 24:192-196. CrossRef Medline

Palokangas H, Metsikkö K, Väänänen K (1994) Active vacuolar H+ATPase is required for both endocytic and exocytic processes during viral infection of BHK-21 cells. J Biol Chem 269:17577-17585. Medline

Paroutis P, Touret N, Grinstein S (2004) The $\mathrm{pH}$ of the secretory pathway: measurement, determinants, and regulation. Physiology (Bethesda) 19: 207-215. CrossRef Medline

Peters SU, Kaufmann WE, Bacino CA, Anderson AW, Adapa P, Chu Z, Yallampalli R, Traipe E, Hunter JV, Wilde EA (2011) Alterations in white matter pathways in Angelman syndrome. Dev Med Child Neurol 53:361367. CrossRef Medline

Presley JF, Cole NB, Schroer TA, Hirschberg K, Zaal KJ, LippincottSchwartz J (1997) ER-to-Golgi transport visualized in living cells. Nature 389:81-85. CrossRef Medline

Repnikova E, Koles K, Nakamura M, Pitts J, Li H, Ambavane A, Zoran MJ,
Panin VM (2010) Sialyltransferase regulates nervous system function in Drosophila. J Neurosci 30:6466-6476. CrossRef Medline

Rivinoja A, Kokkonen N, Kellokumpu I, Kellokumpu S (2006) Elevated Golgi pH in breast and colorectal cancer cells correlates with the expression of oncofetal carbohydrate T-antigen. J Cell Physiol 208:167-174. CrossRef Medline

Rivinoja A, Hassinen A, Kokkonen N, Kauppila A, Kellokumpu S (2009) Elevated Golgi pH impairs terminal N-glycosylation by inducing mislocalization of Golgi glycosyltransferases. J Cell Physiol 220:144-154. CrossRef Medline

Rougeulle C, Glatt H, Lalande M (1997) The Angelman syndrome candidate gene, UBE3A/E6-AP, is imprinted in brain. Nat Genet 17:14-15. CrossRef Medline

Roxrud I, Raiborg C, Gilfillan GD, Strømme P, Stenmark H (2009) Dual degradation mechanisms ensure disposal of NHE6 mutant protein associated with neurological disease. Exp Cell Res 315:3014-3027. CrossRef Medline

Rutishauser U (2008) Polysialic acid in the plasticity of the developing and adult vertebrate nervous system. Nat Rev Neurosci 9:26-35. CrossRef Medline

Sampo B, Kaech S, Kunz S, Banker G (2003) Two distinct mechanisms target membrane proteins to the axonal surface. Neuron 37:611-624. CrossRef Medline

Sato M, Stryker MP (2010) Genomic imprinting of experience-dependent cortical plasticity by the ubiquitin ligase gene Ube3a. Proc Natl Acad Sci U S A 107:5611-5616. CrossRef Medline

Saxon E, Bertozzi CR (2000) Cell surface engineering by a modified Staudinger reaction. Science 287:2007-2010. CrossRef Medline

Schapiro FB, Grinstein S (2000) Determinants of the $\mathrm{pH}$ of the Golgi complex. J Biol Chem 275:21025-21032. CrossRef Medline

Schnaar RL, Lopez PH (2009) Myelin-associated glycoprotein and its axonal receptors. J Neurosci Res 87:3267-3276. CrossRef Medline

Schoch S, Deák F, Königstorfer A, Mozhayeva M, Sara Y, Südhof TC, Kavalali ET (2001) SNARE function analyzed in synaptobrevin/VAMP knockout mice. Science 294:1117-1122. CrossRef Medline

Schroer RJ, Holden KR, Tarpey PS, Matheus MG, Griesemer DA, Friez MJ, Fan JZ, Simensen RJ, Strømme P, Stevenson RE, Stratton MR, Schwartz CE (2010) Natural history of Christianson syndrome. Am J Med Genet A 152A:2775-2783. CrossRef Medline

Schwetz TA, Norring SA, Ednie AR, Bennett ES (2011) Sialic acids attached to O-glycans modulate voltage-gated potassium channel gating. J Biol Chem 286:4123-4132. CrossRef Medline

Seksek O, Biwersi J, Verkman AS (1996) Evidence against defective transGolgi acidification in cystic fibrosis. J Biol Chem 271:15542-15548. CrossRef Medline

Sheikh KA, Sun J, Liu Y, Kawai H, Crawford TO, Proia RL, Griffin JW, Schnaar RL (1999) Mice lacking complex gangliosides develop Wallerian degeneration and myelination defects. Proc Natl Acad Sci U S A 96:7532-7537. CrossRef Medline

Shibuya N, Goldstein IJ, Broekaert WF, Nsimba-Lubaki M, Peeters B, Peumans WJ (1987) The elderberry (Sambucus nigra L.) bark lectin recognizes the Neu5Ac(alpha 2-6)Gal/GalNAc sequence. J Biol Chem 262: 1596-1601. Medline

Simpson MA, Cross H, Proukakis C, Priestman DA, Neville DC, Reinkensmeier G, Wang H, Wiznitzer M, Gurtz K, Verganelaki A, Pryde A, Patton MA, Dwek RA, Butters TD, Platt FM, Crosby AH (2004) Infantile-onset symptomatic epilepsy syndrome caused by a homozygous loss-offunction mutation of GM3 synthase. Nat Genet 36:1225-1229. CrossRef Medline

Slepkov ER, Rainey JK, Sykes BD, Fliegel L (2007) Structural and functional analysis of the $\mathrm{Na}^{+} / \mathrm{H}^{+}$exchanger. Biochem J 401:623-633. CrossRef Medline

Stocker PJ, Bennett ES (2006) Differential sialylation modulates voltagegated $\mathrm{Na}^{+}$channel gating throughout the developing myocardium. J Gen Physiol 127:253-265. CrossRef Medline

Swift F, Franzini-Armstrong C, Øyehaug L, Enger UH, Andersson KB, Christensen G, Sejersted OM, Louch WE (2012) Extreme sarcoplasmic reticulum volume loss and compensatory T-tubule remodeling after Serca2 knockout. Proc Natl Acad Sci U S A 109:3997-4001. CrossRef Medline

Takashima S (2008) Characterization of mouse sialyltransferase genes: their evolution and diversity. Biosci Biotechnol Biochem 72:1155-1167. CrossRef Medline 
Tartakoff A, Vassalli P, Détraz M (1978) Comparative studies of intracellular transport of secretory proteins. J Cell Biol 79:694-707. CrossRef Medline

Thorens B, Vassalli P (1986) Chloroquine and ammonium chloride prevent terminal glycosylation of immunoglobulins in plasma cells without affecting secretion. Nature 321:618-620. CrossRef Medline

Tyrrell L, Renganathan M, Dib-Hajj SD, Waxman SG (2001) Glycosylation alters steady-state inactivation of sodium channel Nav1.9/NaN in dorsal root ganglion neurons and is developmentally regulated. J Neurosci 21 : 9629-9637. Medline

Ueno T, Sekine T (1981) A role of $\mathrm{H}^{+}$flux in active $\mathrm{Ca}^{2+}$ transport into sarcoplasmic reticulum vesicles: II. $\mathrm{H}^{+}$ejection during $\mathrm{Ca}^{2+}$ uptake. J Biochem 89:1247-1252. Medline

van Vliet C, Thomas EC, Merino-Trigo A, Teasdale RD, Gleeson PA (2003) Intracellular sorting and transport of proteins. Prog Biophys Mol Biol 83:1-45. CrossRef Medline

Varki A (2006) Nothing in glycobiology makes sense, except in the light of evolution. Cell 126:841-845. CrossRef Medline

Varki A (2007) Glycan-based interactions involving vertebrate sialic-acidrecognizing proteins. Nature 446:1023-1029. CrossRef Medline

Varki A (2008) Sialic acids in human health and disease. Trends Mol Med 14:351-360. CrossRef Medline

Varki A, Cummings RD, Esko JD, Freeze HH, Stanley P, Bertozzi CR, Hart GW, Etzler ME (2009) Essentials of glycobiology, Ed 2. Cold Spring Harbor, NY: Cold Spring Harbor Laboratory.

Vocadlo DJ, Hang HC, Kim EJ, Hanover JA, Bertozzi CR (2003) A chemical approach for identifying O-GlcNAc-modified proteins in cells. Proc Natl Acad Sci U S A 100:9116-9121. CrossRef Medline

Wallace ML, Burette AC, Weinberg RJ, Philpot BD (2012) Maternal loss of Ube3a produces an excitatory/inhibitory imbalance through neuron type-specific synaptic defects. Neuron 74:793-800. CrossRef Medline
Weinstein IB, Orenstein JM, Gebert R, Kaighn ME, Stadler UC (1975) Growth and structural properties of epithelial cell cultures established from normal rat liver and chemically induced hepatomas. Cancer Res 35:253-263. Medline

Williams CA (2010) The behavioral phenotype of the Angelman syndrome. Am J Med Genet C Semin Med Genet 154C:432-437. CrossRef Medline

Winckler B (2004) Scientiae forum/models and speculations pathways for axonal targeting of membrane proteins. Biol Cell 96:669-674. CrossRef Medline

Xiang M, Mohamalawari D, Rao R (2005) A novel isoform of the secretory pathway $\mathrm{Ca}^{2+}, \mathrm{Mn}(2+)$-ATPase, hSPCA2, has unusual properties and is expressed in the brain. J Biol Chem 280:11608-11614. CrossRef Medline

Yamasaki K, Joh K, Ohta T, Masuzaki H, Ishimaru T, Mukai T, Niikawa N, Ogawa M, Wagstaff J, Kishino T (2003) Neurons but not glial cells show reciprocal imprinting of sense and antisense transcripts of Ube3a. Hum Mol Genet 12:837-847. CrossRef Medline

Yashiro K, Riday TT, Condon KH, Roberts AC, Bernardo DR, Prakash R, Weinberg RJ, Ehlers MD, Philpot BD (2009) Ube3a is required for experience-dependent maturation of the neocortex. Nat Neurosci 12: 777-783. CrossRef Medline

Yu RK, Nakatani Y, Yanagisawa M (2009) The role of glycosphingolipid metabolism in the developing brain. J Lipid Res 50 [Suppl]: S440-S445. CrossRef Medline

Yu X, Inesi G (1993) Effects of anions on the $\mathrm{Ca}^{2+}, \mathrm{H}^{+}$and electrical gradients formed by the sarcoplasmic reticulum ATPase in reconstituted proteoliposomes. FEBS Lett 328:301-304. CrossRef Medline

Zheng L, Ding H, Lu Z, Li Y, Pan Y, Ning T, Ke Y (2008) E3 ubiquitin ligase E6AP-mediated TSC2 turnover in the presence and absence of HPV16 E6. Genes Cells 13:285-294. CrossRef Medline 